\title{
PRICING AND TRADING PRACTICES OF COUNTRY ELEVATORS IN MISSOURI
}

A Thes1s

Presented to

the Faculty of the Graduate School

The Un1vers1ty of M1s sour1

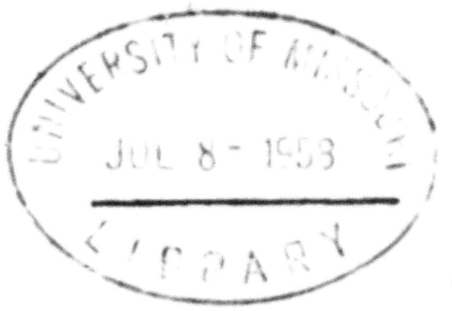

In Partial Fulfillment.

of the Requirements for the Degree

Master of Sclence

by

Dorwin L. W1111ams

June 1958 
The undersigned, appointed by the Dean of the Graduate Faculty, have examined a thesis entitled :

PRICING AND TRADING PRACTICES OF COUNTRY ELEVATORS IN MISSOURI

presented by

Darwin L. W1111ams

a candidate for the degree of

Master of Science

and hereby certify that in their opinion it is worthy of acceptance.

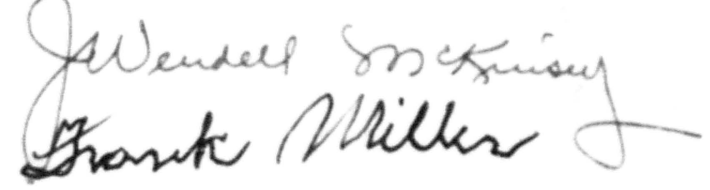
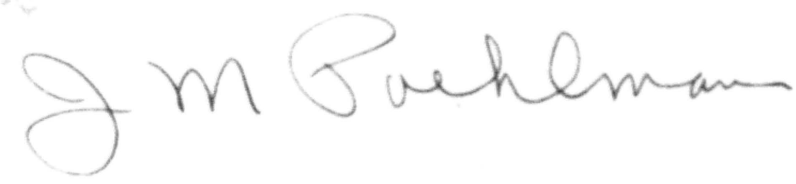


\section{ACKNOWLEDGMENT}

I wish to extend grateful appreciation to Professors J. Wendell MoKinsey and Dav1d $\mathbb{N}$. Harrington for their guidance in developing this study, and for their assistance In presenting the ansiysis. 
TABLE OF CONTENTS

CHA PTER

PAGE

I. INTRODUCTION . . . . . . . . . . . . . . . 1

Purpose of the study . . . . . . . . . . 3

Scope and Method . . . . . . . . . . . 4

Definitions of Terms Used.......... 5

Grain Production in Missour1....... . 6

Grain Marketing Developments in M1ssour1 . . . 13

Abstract of Succeeding Chapters. . . . . . 16

II. GRAIN PRICING . . . . . . . . . . . . . . I8

Sources of Pricing Information ....... 20

Changes in source of pricing information

since 1946 . . . . . . . . . . . . 22

Comparison of Grain Prices Among the Crop

Report1ng D1str1ets in M1ssour1. . . . . 22

Relationship of grain prices at the farm

and at terminal markets. . . . . . . 27

III. MARKETING MARGINS FOR COUNTRY GRAIN ELEVATORS. . 29

Gross Margins for Fifty-Nine Country Grain

Elevators in Missouri for Grain Shipped by

Ra11, by Truck, and Sold Locally . . . . . 30

Comparison of gross margins for large and

small elevators. . . . . . . . . 35

Comparison of gross margins among the three

types of f1rm ownersh1p. . . . . . . 36 
CHAPTER

PAGE

Comparison of gross margins among the

Missour1 Crop Report1ng Districts. . . . 39

Changes in gross margins since 1946..... 47

IV. METHODS OF SALE FOR COUNTRY GRAN ELEVATORS . . 50

Sales Outlets............... 51

Transportation Methods Used. . . . . . . 57

Financing trucked grain shipments. . . . . 59

v QUALITY DETERMINATION OF GRAIN . . . . . . . 62

Development of Grain Grading . . . . . . 64

Grain Grading Factors. . . . . . . . . 66

Practices in grain sarnpling. . . . . . 68

Changes in grading practices since 1946. . . 70

Grain merchandising practices. . . . . . 72

VI. STMMARY AND CONCLUSIONS. . . . . . . . . . 73

BIBLIOGRAPHY . . . . . . . . . . . . . . . . 77

APPENDIX . . . . . . . . . . . . . . . . 80 


\section{IIST OF TABLES}

TABLE

PAGE

I. Cash Farm Income from the Sale of Grain, and

Livestock and Livestock Products, Missour1

Farmers, 1955 and 1956 . . . . . . . . 2

II. Per Cent Each Grain was of Total Grains Produced,

Production of Major Grains, and Rank Among All

States in Grain Product1on, M1ssour1, 1956 .

III. Production of Major Grains by Crop Reporting

Districts, M1ssour1, 1955 ........ 8

IV. Ten Year Average Annual Grain Production by Grop

Reporting Districts, and the Per Cent of the

Stete's Total Grain that wes Produced in Each

Crop Reporting D1strict, M1ssour1, 194.6-1955.

V. Por Cent of the State's Total Production of Each

Kind of Grain that was Grown in Each Crop Re-

por'ing Distrlet, Based on Ten Year's Product1on, M1ssour1, 1946-1955 ..........

VI. A Comparison of Storage Capacity Versus Volume of Grain Handlod, by Type of Firm Ownersh1p, for F1fty-nine Country Elevators, M1ssour1,

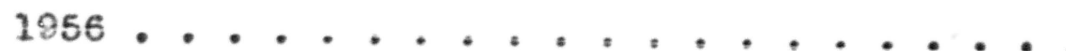

VII. Sources of Pricing Information and Per Cent of Grain that was Bought Based on Price Information from Each Source, Fifty-nine Country Elevators, M1souri, 1956 . . . . . . . 
VIII. Eleven Year Average Price per Bushel Recelved by Farmers, and Average Price per Bushel Paid at a Terminal Market for Corn, Wheat, Soybeans, and Oats; 1946-1956, Inclus1ve . . . . . . 23

IX. Gross Margins of Fifty-nine Country Elevators for Grain Sh1pped by Ra11, Truck, and Sold Locally, M1ssour1, 1956 . . . . . . . . . . 31

x. Comparison of the Gross Margins of Large Elevators and Small Elevators, by Kind of Grain, Fifty-nine Country Elevators, M1ssour1, 1956 - 37

XI. Gross Margins of Fifty-nine Country Elevators, Grouped According to Type of Firm Owmersh1p, for Ra11 Shipments, Truck Shipments, and Iocal Sales of Gra in, Missour1, 1956 . . . . 38 XII. Gross Margins of Fifty-nine Country Elevators for Grain Sh1pped by Ra11, by Crop Reporting D18tr1cts, M1ssour1, 1956 ........... 42 XII. Gross Margins of Fifty-nine Country Elevators for Grain Shipped by Truck, by Crop Reporting Distr1cts, M1ssour1, 1956 . . . . . . . 43

XIV. Gross Margins of Fifty-nine Country Elevators for Grain Sold Locally; by Crop Reporting Districts, M1ssour1, 1956 
XV. Changes in Gross Margins on Grain Since 1946, Fifty-nine Country Elevators, M1ssour1, 1956 • 49

XVI. Per Cent of Total Volume of Each Kind of Grain Sold, Going Through Each Sales Outlet, Flftynine Country Elevators, M1ssour1 1956 ... 52

XVII. Per Cent of All Grain sold That Went Through Each Sales Outlet, Fifty-nine Country Elevators, M1ssour1, 1956 . . . . . . 56

XVIII. Per Cent of Each Kind of Grain Going Through Each Outlet; Per Cent of All Grain Going Through Each Outlet; and the Per Cent Each Grain was of Total Volume of All Grain Sold, Fifty-nine Country Elevators, M1ssour1, 1956 . 58

XIX. Methods of Flnancing Trucked Grain Shipments, Expressed as a Per Cent of Total Volume of Grain Sh1pped by Truck, F1fty-nine Country Elevators, Missour1, 1956 ....... 60

XX. Changes in Grading Pract1ces Since 1946, P1ftynine Country Elevators, M1ssour1, $1956, \ldots 71$ 


\section{IIST OF APPENDIX TABLES}

TABLE

PAGE

I. Average Price per Bushel Received by Farmers, and Average Price per Bushel Paid at

Terminal Market for Corn, 1946-1956 ......

II. Average Price per Bushel Recelved by Farmers, and Average Price per Bushel Paid at a Terminal Market for Wheat, 1946-1956 . . . 82 III. Average Price per Bushel Recelved by Farmers, and Average Price per Bushel Pald at a Terminal Markpt for Soybeans, 1946-1956 ....

IV. Average Price per Bushel Recelved by Farmers, and Average Price per Bushel Paid at a Terminal Market for Oats, 194€-1956 . . . . 84

V. Per Cent of Grain Sold from the Farm, 1955 - • 85 VI. Por Cent of the State's Total Number of Each Class of Livestock in Each D1strict, M1ssour1, January 1, 1956 ........... 86 


\section{IIST OF FIGURES}

FIGURE

PACE

1. M1ssour1 Crop Reporting Districts . . . . . . 10

2. Range in Margins on Ra1l Shipments of Five Grains, Fifty-nine Country Elevators, M1ssour1, 1956 . 34

3. Sele Outlets Expressed as a Per Cent of the Total

Volume of all Grain Sold, Fifty-nine Country Elevazors, M1ssour1, $1956 . . . . . . . . .$.

4. Average Gross Margins on Ra11 Sh1pments of Four Grains, by Crop Reporting D1stricts, F1fty-nine Country Elevators, M1ssour1, 1956 .. . . . . 


\section{CHAPTER I}

\section{INTRODUCTION}

M1ssour1 farmers recelved an income in 1956 of approximately $\$ 253,000,000$ directly from the sale of grain. This amount represents nearly 25 per cent of their cash farm recelpts, and 1 ts importance as a source of farm Income in M1ssourl was exceeded only by the sale of 11vestock. (See Table I.) When 11vestock are considered as just another form in wh1ch grain may be marketed, the 1mportance of grain to farm income 1s shown even more cleerly.

Country grain elevators are the sales outlet for about 80 to 90 per cent of the grain which farmers sell.1 This would indicate that the pricing and trading practices of country elevators play a somewhat important role in the grain producer's economy.

It 18 the function of price to communica the consumers' desires, preferences, and appraisal of quality back to the producer. If the comminication is perfect, there is perfect allocation of resources to grain production. The producer of premium quality is rewarded with a premium price, and the price of low quality grain is alscounted.

${ }_{\text {R1chard L. Kohls, Market1ng of Agr1cultural Products }}$ (New York: The Macm1lian Company, 1955), p. 277 . 
TABLE I.

CASH FARM INCOME FRON THE SALE OF GRAIN, AND LIVESTOCK AND LIVESTOCK PRODUCTS, NISSOURI FARMERS, 1955 AND 1956*

\section{$\underline{1955}$}

$\underline{1956}$

L1vestock and L1vertock Products: \$615,959,000\$660,184,000 Grain:

Wheat $87,036,000 \quad 38,524,000$

Soybeans $75,643,000 \quad 80,279,000$

Corn $51,016,000 \quad 73,255,000$

Oats $6,185,000 \quad 5,675,000$

Barley $2,350,000 \quad 2,371,000$

Sorghum Grains $809,000 \quad 2,071,000$ Rye 706,000 538,000

Total'tor Grains: $\$ 223,745,000 \$ 252,713,000$

* State Agricultural stet1st1cian. 
Imperfections in this communication process prevent the measuring and reflecting of quality differences correctly. Price differentials and related grain movements are brought about by many factors, including supply and demand shifts, and transporitation costs. Knowledge of value to farmers, the grain trade, and others can be Improved by analyzing the forces causing price patterns and grain movement changes. Information on the performance of price in reflecting demand may ald the producer in making the dec1sion of when and where to market grain.

\section{PURPOSE OF THE STUDY}

The purpose of the study is to obtain information concerning the pricing and trading practices of country grain elevators in M1ssourl that will be of value to grain producers, elevator operators, and others who are interested in grain marketing erficiency.

An attempt was made to learn the current sources of pricing information used by country elevator operators, their marketing margins, methods of sale, and practices omployed in quality determination of grain.

As more information on grain marketing is made avallable, there will be a tendency for 1ncreased eff1clency in the process of moving grain and 1ts products from producers to consumers. 
II. SCOPE AND METHOD

Pricing and trading practices data frow country elevators were secured on survey questionnalres by perscpal interviews with the elevator owner or his manager.

The sample consisted of a 10.5 per cent sample of elevator firms in M1ssour1 drawn as follows: 75 per cent from the upper 50 per cent and 25 per cent from the lower 50 per cent in volume of grain handled a s reported for the North Central Regional Marketing Study NCM-B-2- schedule. For the proportion of the population for which volume was not avallable, the same procedure was followed, except for subst1tuting total storage capacity for volume of grain handled. The sample was dram by M1sourl Crop Reporting Districts, with no minimum size sample required from a Distriet.

The personal interviews were made during the summer of 1957. The elevator operator, or his representative, was asked to base his answers on the previous year's operat1on $(1956)$.

It may be emphasized that estimates were given for most of the data, however the estimates were made by the person most intimately acquainted with the firm's operat1on. In some instances complete information was not ava1lable due to a change in recent management, however it 18 belleved that the Information collected represent a 
reasonable degree of accuracy.

III. DEFINITIONS OF TERMS USED

Country Elevator. A $11 \mathrm{rm}$ wh1ch is engaged in

purchasing grain directly from the producer for the purpose of resale through unprocessed graln channels.

Terminal Markets. Grain markets which recelve all of their grain from other elevators.

Car-lot dealers or brokers. Those dealers that buy only in car-load lots. Also dealers and commission firms that act as brokers and charge a fee for selling the grain on the market.

Terminal Quotation. Price of grain as quoted by a terminal market.

Processors. Firms which are engaged in grinding, mixing, pressing or otherwise changing the form of the raw grain.

Sub-terminal Elevators. Elevators which recelve between 50 and 90 per cent of their grain from other elevators, and the remainder direct from the producer.

Truckers. People who buy grain from an elevator and transport it by truck in order to sell it to another person or agency.

Local Feeders. Persons in the local trade area who buy grain for the purpose of feeding 1t to l1vestock, 
Home Office. A firm's headquarters which 1s located in some other town.

Gross Margin. The amount charged per bushel for handleg the grain.?

Scalping. The process of removing major forelgn material from grain.

Cleaning. The removal of all forelgn material from grain.

Blending. The process of mixing two or more grades of grain in order to ralse the grade and value of the lot.

Iocal Salese Grain sold to local feeders and mills. Consigned to Terminals. Grain consigned to a terminal agency for sale.

Inter10r Points. Markets not located at the major terminals.

Large Elevator. An elevator among the upper 50 per cent in volume of grain handled or storage capacity.

Sma11 Elerator. An elevator among the lower 50 per cent in volume of grain handled or storage capacity.

\section{GRAIN PRODUCTION IN MISSOURI}

M1ssour1 is an important producer of all the major grains. As show in Table II, 1t ranked between f1fth and ninth place among all states in the production of the seven main grain crops grown in the United States for the year 


\section{TABLE II}

PER CENT EACH GRAIN WAS OF TOTAL GRAINS PRODUCED, PRODUCTION OF MAJOR GRAINS, AND RANK AMONG ALL STATES IN GRAIN PRODUCTION, MISSOURI, 1956*

\begin{tabular}{|c|c|c|c|}
\hline Grain & $\begin{array}{l}\text { Per cent each } \\
\text { grain was of } \\
\text { total gra ins } \\
\text { produced in Mo. }\end{array}$ & $\begin{array}{l}\text { Production } \\
\text { for Mo. } \\
\text { (busheis) }\end{array}$ & $\begin{array}{l}\text { M1sour1's } \\
\text { rank in } \\
\text { production }\end{array}$ \\
\hline Corn & 55.9 & $189,408,000$ & 6 \\
\hline Wheat & 14.7 & $49,800,000$ & 8 \\
\hline Oats & $12 \cdot 4$ & $42,128,000$ & 9 \\
\hline Soybeans & 11.6 & $39,120,000$ & 5 \\
\hline Barley & 3.5 & $11,826,000$ & 8 \\
\hline Sorghum Grains & 1.7 & $5,610,000$ & 8 \\
\hline Rye & .2 & 765,000 & 7 \\
\hline 00 & 100.0 & $338,658,000$ & \\
\hline
\end{tabular}

* Crop Production July, 1957, and October, 1957, United states Department of Agricuiture, Agricuitural Marketing Service, Washington, D. C. 
TABLE III

PRODUCTION OF MAJOR GRAINS BY CROP REPORTING DISTRICTS, MISSOURI, 1955*

\begin{tabular}{|c|c|c|c|c|c|c|c|c|}
\hline \multicolumn{2}{|c|}{ D1strict } & Corn & Wheat & $\frac{\text { In }}{\text { Oats }}$ & $\begin{array}{c}\text { thousands } \\
\text { Soybeans }\end{array}$ & $\frac{\text { of bushel }}{\text { Barley }}$ & $\begin{array}{l}\text { Sorghum } \\
\text { Grain }\end{array}$ & Rye \\
\hline$I$ & (Northwest) & 38,550 & 8,600 & 8,863 & 2,892 & 338 & 424 & 88.6 \\
\hline II & (North Central) & 24,768 & 4,856 & 6,414 & 5,746 & 436 & 313 & $88 \cdot 6$ \\
\hline III & (Northeast) & 20,982 & 5,101 & 5,593 & 7,838 & 497 & 12 & 75.7 \\
\hline IV & $(W e s t)$ & 14,810 & 6,269 & 8,575 & 1,238 & 3,737 & 347 & 119.2 \\
\hline $\mathbf{v}$ & (Central) & 25,356 & 8,338 & 8,995 & 1,555 & 3,204 & 505 & $130 \cdot 2$ \\
\hline VI & (East) & 16,461 & 5,855 & 2,717 & 1,398 & 1,341 & 45 & 60.5 \\
\hline VII & (Southwest) & 4,048 & 5,130 & 5,529 & 618 & 3,377 & 534 & 159.0 \\
\hline VIII & (South Central) & 4,288 & 1,526 & 1,535 & 198 & 402 & 99 & $43 \cdot 2$ \\
\hline IX & (southeast) & 15,941 & 2,406 & 811 & 12,467 & 693 & 46 & 257.0 \\
\hline State & & 165,204 & 48,081 & 49,032 & 33,950 & 14,025 & 2,325 & $1,022.0$ \\
\hline
\end{tabular}

HM1sour1 Farm Census by Count1es, 1955, (M1ssour1 State Department of Agricul-

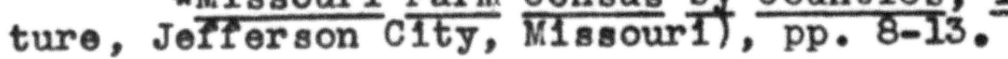


1956.

M1ssour1 is divided into nine Crop Reporting D1stricts. Within the Districts are found relatively homogeneous conditions as relates to soll and climatic cond1t1ons. Ses F1gure 1, for a map indicating the geographical locations of the Crop Reporting Districtd.

District I (Northwest) is the most important grain producing district of the nine Crop Reporting Districts in M1ssour1. Of the total bushels of all grain produced in M1ssour1 during the ten year per1od 1946-1855, D1strict I accounted for an average of 20.6 per cent, followed by District V (Central) w1th 13.4 per cent of the state's total grain production. (Table IV.)

In the production of the various classes of grain, District I led in the production of corn and osts and had a very close second place for wheat production after D1strict VI (East). D1strict IX (Southeast) led in the production of soybeans and rye, while District VII (Southwest) was first in the production of barley. District IV (West) had by far the largest production of sorghum grains. District VIII (South Central) ranked lowest in grain production, but not in the number of 11vestock (See Appendix Table VI, p.86); therefore it is a grain deficient area.

The production of all the major grains in Missourl has tended to increase over the pest two decades, however, 


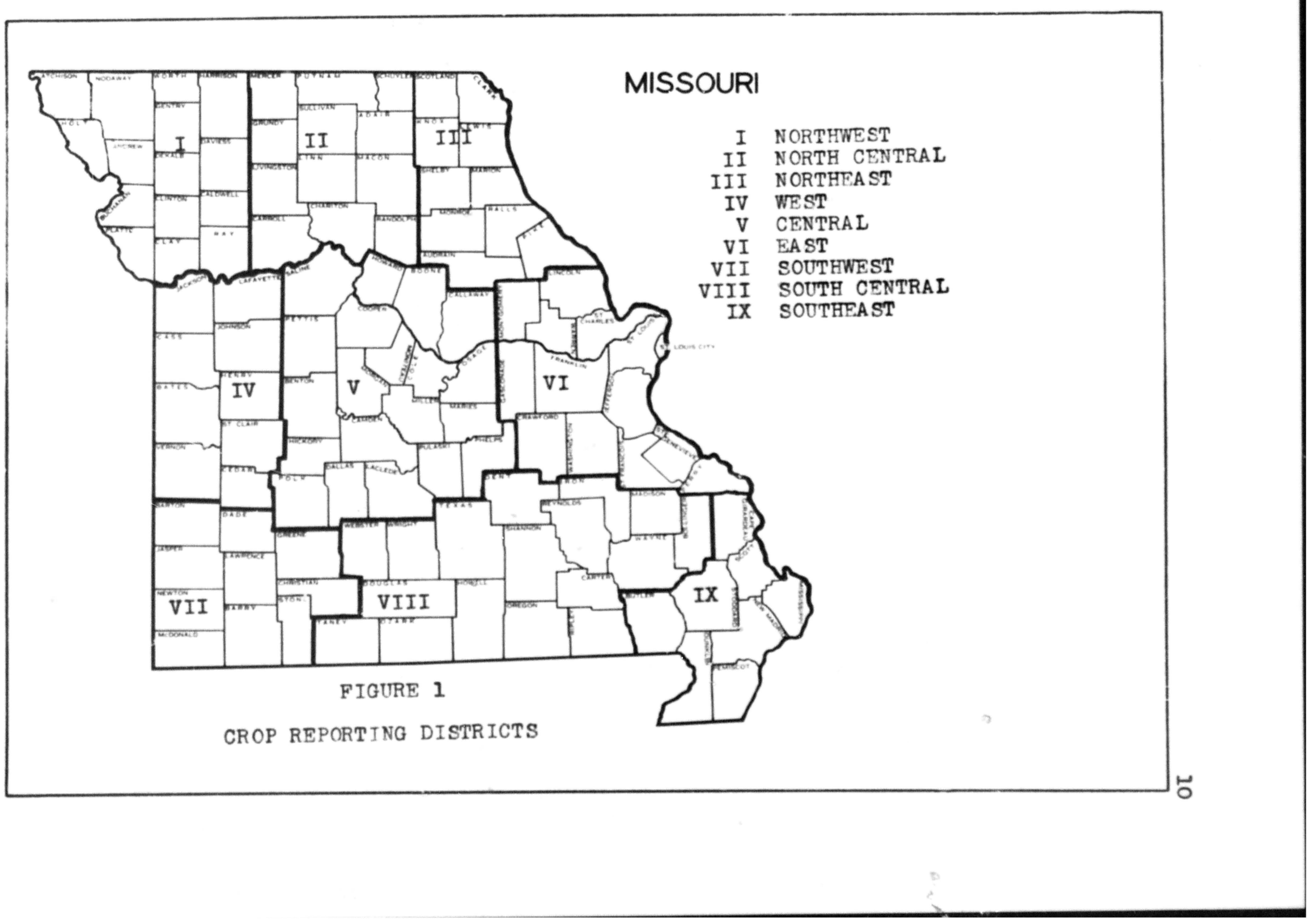




\section{TABLE IV}

TEN YEAR AVERAGE ANNUAL GRAIN PRODUCTION BY CROP REPORTING DISTRICTS,

AND THE PER CENT OF THE STATE'S TOTAL GRAIN THAT WAS PRODUCED

IN E.ACH CROP REPORTING DISTRICT, MISSOURI, 1946 - 1955*

\begin{tabular}{|c|c|c|c|c|c|c|c|c|c|c|}
\hline \multirow[b]{2}{*}{ Gra1n } & \multicolumn{10}{|c|}{ M1ssour1 Crop Reporting Districts } \\
\hline & $I$ & $I I$ & III & IV & $V$ & VI & VII & VIII & IX & State \\
\hline & & & & & & & & & & \\
\hline Corn & 38,090 & 20,254 & 17,762 & 16,600 & 20,462 & 13,736 & 4,994 & 4,277 & 13,615 & 149,798 \\
\hline Oats & 7,349 & 5,157 & 4,856 & 7,088 & 6,862 & 2,508 & 6,292 & 1,713 & 706 & 42,531 \\
\hline Wheat & 5,206 & 2,952 & 3,327 & 4,025 & 4,909 & 5,269 & 3,550 & 878 & 1,815 & 31,931 \\
\hline Soybean 8 & 1,160 & 3,460 & 5,913 & 1,011 & 798 & 836 & 616 & 104 & 9,256 & 23,154 \\
\hline Barley & 60 & 67 & 73 & 699 & 610 & 505 & 974 & 200 & 274 & 3,462 \\
\hline Sorghum Grains & 74 & 93 & 34 & 313 & 124 & 9 & 134 & 20 & 16 & 817 \\
\hline Rye & 53 & 37 & 42 & 61. & 56 & 62 & 77 & 25 & 126 & 539 \\
\hline
\end{tabular}

Total, all grain $52,00032,02032,00729,79733,82122,92516,6377,21725,808252,232$ $\begin{array}{llllllllllll}\text { Per cent } & 20.6 & 12.7 & 12.7 & 11.8 & 13.4 & 9.1 & 6.6 & 2.9 & 10.2 & 100.0\end{array}$

*M1ssour1 Farm Census By Count1es, 1946 to 1955, M1ssour1 State Department of Agriculture, Jefferson C1ty, M1sour1. 


\section{TABLE V}

PER CENT OF THE STATE'S TOTAL PRODUCTION OF EACH KIND OF GRAIN THAT WAS GROWN IN EACH CROP REPORTING DISTRICT, BASED ON TEN YEAR'S PRODUCTION,

$$
\text { MISSOURI, } 1946 \text { - 1955* }
$$

\begin{tabular}{|c|c|c|c|c|c|c|c|c|c|c|}
\hline \multirow{3}{*}{ Grain } & \multirow[b]{2}{*}{$I$} & \multicolumn{9}{|c|}{ M18sour1 Crop Roporting districts } \\
\hline & & II & III & IV & $\frac{\vec{v}}{\mathrm{P} \theta \mathrm{r}}$ & $\frac{\sqrt{I}}{\operatorname{con} t}$ & VII & VIII & IX & $\frac{\text { State }}{\text { Total }}$ \\
\hline & 25.4 & 13.5 & 11.9 & 11.1 & 13.7 & 9.2 & 3.3 & 2.8 & 9.1 & 100.0 \\
\hline Oats & 17.3 & 12.1 & 12.4 & 16.7 & 16.1 & 5.8 & 14.8 & 4.0 & 1.7 & 100.0 \\
\hline Wheat & 16.3 & 9.3 & 10.5 & 12.6 & 15.4 & 16.5 & 11.2 & 2.5 & 5.7 & 100.0 \\
\hline Soybeans & 5.0 & 14.9 & 25.5 & 4.4 & 3.4 & 3.6 & 2.7 & .5 & 40.0 & 100.0 \\
\hline Barley & 1.7 & 1.9 & 2.1 & 20.6 & 17.5 & 14.5 & 28.1 & 5.7 & 7.9 & 100.0 \\
\hline Sorghum grains & 9.0 & 11.3 & 4.1 & 38.4 & 15.2 & 1.1 & 16.4 & 2.5 & 2.0 & 100.0 \\
\hline Rye & 9.9 & 6.9 & 7.7 & 11.3 & 10.4 & 11.5 & 14.3 & 4.7 & 23.3 & 100.0 \\
\hline
\end{tabular}

-M1s sour1 Farm Census By Count1es, 1946 - 1955, M1ssour1 State Department of Agr1culture, Jefferson C1t M1s sour1. 
the largest growth has been in the production of soybeans, sorghum grains and barley. Th1s has come about malnly because of Improved varieties, mechanization, acreage control programs, and the occurrence of droughts which discouraged depondence upon corn as a grain crop in some areas of the state.

\section{GRAIN MARKETING DEVELOPNENTS IN MISSOURI}

Many changes in production and marketing of grains have occurred during the past twenty years. The increased production of soybeans, greater yleld of corn, and new wheat and grain sorghum varleties have created changes in price patterns, both seasonally and locat1onally. Development of combines, corn plckers, and motor trucks have forced many changes in marketing and pricing methods. These mechanical 1nnovations have shortened the harvest period conslderably, and have greatly increased the dally volume of grain which a country elevator mast be prepared to handle.

Prior to the development of motor trucks 1t was necessary for the country elevators to be located close to the farms from which it recelved 1ts grain. This situation encouraged the development of a large number of small firms. Today, with good roads and motor trucks, distance is not the barrier for farmers that it once was in marketing their 
grain. When the grain is losded on the truck, and with good roads, the farmer does not hesitate to drive a few miles further in order to recelve a higher price for his grain. It is reasonable to belleve that this has signiflcantly increased competition among country elovacors for the farmers' grain.

A large percentage of the farmer's cash grain first enters the commercial marketing channel when it is sold to the country elevator. From here most of 1 t is sent to terminal elevators, or to various processors where 1t may be changed into many different products before final consumption.

Ownership of these country grain marketing channels 1s vested in business units organized as (1) a privately owned firm operating several plants, (2) a privately owned single plant operation, and (3) cooperatives.

In the sample of 59 country elevators drawn for this study it was found that there were 17 being operated by a firm which owned seversl elevators; 28 which were single plant operations; and 14 cooperatively owned elevators. The elevators which were operated by a f1rm that operated several plants had the greatest average storage capacity and also the largest average volume of grain handled. (Table VI.)

However, 1t was observed that the firms organized as stated above in (1), (2), and (3) had ratios of volume 


\section{TABLE VI}

A COMPARISON OF STORAGE CAPACITY VERSUS VOLUME OF GRAIN HANDLED, BY TYPE OF FIRM OWNERSHIP, FOR FIFTY-NINE COUNTRY ELEVATORS,

$$
\text { MISSOURI, } 1956
$$

\begin{tabular}{|c|c|c|c|c|c|c|c|c|c|c|}
\hline \multirow{2}{*}{$\begin{array}{l}\text { Type } \\
\text { of } \\
\text { Firm }\end{array}$} & \multirow{2}{*}{$\begin{array}{l}\text { Number } \\
\text { of } \\
\text { Elevator } 8\end{array}$} & \multicolumn{8}{|c|}{ (In thousands of bushels) } & \multirow{2}{*}{$\begin{array}{l}\text { Rat10 of } \\
\text { Volume to } \\
\text { Storage Capac1ty }\end{array}$} \\
\hline & & TotaI & $\begin{array}{l}\text { Stor } \\
\text { Av. }\end{array}$ & Med1an & Range & Total & $\begin{array}{l}\text { Vol } \\
\text { Av. }\end{array}$ & Med1an & Range & \\
\hline (a) * & 17 & 1,221 & 72 & 75 & $5-230$ & 5,263 & 310 & 230 & $4-871$ & $4.3: 1$ \\
\hline$(\mathrm{b}) *$ & 28 & 1,072 & 38 & 25 & $4-200$ & 6,490 & 232 & 177 & $5-1,210$ & $6.1: 1$ \\
\hline (c)* & 14 & 612 & 44 & 26 & $6-200$ & 2,608 & 186 & 152 & $7-752$ & $4.3: 1$ \\
\hline Total & 59 & 2,905 & 49 & 28 & $4-230$ & $14,3 \in 1$ & 243 & 177 & $4-1,210$ & $4.9: 1$ \\
\hline
\end{tabular}

* (a) Firm operating several elevators (privately owned).

* (b) single elevator operation (privately owned).

(c) Cooperat1ve owned elevators. 
handled to storage capacity of approximately $4: 1,6: 1$, and 4:1, respectively. This would indicate that 1t was the single plant operations which had the higher degree of facility utilization in this particular study.

The 59 country grain elevators included in this study, had an average storage capacity of 49,000 bushels, and the average volume of grain handled during 1956 was 243,000 bushels. (Table VI.) Their rat10 of volume handled to storage capacity was approximately $4.9: 1$.

For the years 1955 and 1956 the sale of wheat, soybeans, and corn accounted for approximately 95 per cent of the cash recelpts for all grain sold by Missourl farmers. (Table I.) of these, wheat was the most important cash grain crop, followed next by soybeans, and then corn. It appears very likely that soybeans may replace wheat as the main cash crop for Missour1 in the near future.

\section{ABSTRACT OF SUCCEEDING CHAPTERS}

In the succeeding chapters the trading and pricing practices of country elevators will be dealt with in an attempt to better understand the 1mpact of these factors on the efficlency of grain marketing in the state of Missourl. In Chapter II, the pricing information used by country elevators w1ll be examined: the sources of pricing informat1on, and to what extent recent changes have occurred in 
this fleld. Farm prices for grain in the varlous Crop Reporting Districts in Missouri will be compared and their relationship to terminal prices discussed.

Chapter III w1ll deal with marketing margins charged by country elevators. Present gross margins will be examIned; comparisons of margins will be made by size of f1rm, type of sales outlet, by type of firm ownership, and by Crop Reporting District. Changes in margins during the past ten years, and the causes of these changes, w1ll be discussed.

In Chapter IV the methods of sale used by country grain elevators will be examined. The sales outlets, the methods of transportation, and how trucked grain shipments are financed w1ll each be discussed.

Chapter V w1ll deal with quality determination and grain grading. An attempt w1ll be made to discover the existing grain grading practices at the country elevatior, and the changes in grading practices over the past decade. The merchandising practices of country grain elevators will also be examined. Chapter VI will surmarize the findings of the research. 
CHAPTER II

GRAIN PRICING

Price may be defined as value in terms of money; with value being the power of one commodity to command another commodity in exchange.

In a free, competitive soclety prices guide the production, distribution, and consumption of commodities. Higher prices will induce producers and sellers to try to increase supply and sales. However, an increased price w11l have a tendency to reduce the quant1ty which buyers and consumers will take. Thus, the price at which the commodity w1ll clear the market reflects the influences of buyers, sellers, producers, and consumers. In the establishment of price for grain the basic forces contributing to th1s flgure may be summed up and placed under the titles of supply and demand. However, these two simple titles cover a multitude of causative or contributing factors. In the case of grain prices, it not only is the present demand and supply siturtion that makes an impression on the market, but also anticipated situations for the months ahead. These anticlpations are expressed and impressed on the market for grain by trading in the grain futures market. In recent years governmental price support programs have also played an important role in 
establishing grain prices and pricing techniques.

Several programs of the Unfted States Department of Agriculture contribute to grain price determination. The most important of which are the price-support programs. These bring into the market place an additional type of buyer; the Government -- a potent1al buyer with relatively unlimited financial resources. The Government competes w1th comnercial buyers, but unlike tham 1ts objective is to stablize or ralse prices recelved by farmers rather than to make a profit on 1ts operations.

Futures markets are of direct interest to farmers because futures prices are used as base prices in the buying and selling of cash commodities. Futures prices influence cash prices whether the buying and selling of the cash commodity takes place on the floor of the Kansas City Board of Trade, whether 1t centers around the commod1ty exchanges that are not futures markets, or whether 1t takes place at hundreds of locel markets where grain is sold.

In the final analysis it is supply and demand throughout the world that decides what the price for grain w1ll be, whether it be cash wheat in carloads sold on the table or futures orders traded in the p1t of the board of trade. The present and prospective stocks of grain, the consumer's income, bis tostes, and his willingness to buy, 
governmental pollcies, and forelgn trade prospects are all considered and we1ghed by grain traders. Therefore, it is th1s mult1tude of forces, which go into making supply and demand, all compet1tively operating in a market, that ultimately, and collectively determine the price for grain.

\section{SOURCES OF PRICING INFORMATION}

In this study, the elevator operator was a sked to estimate the number of bushels of each grain which he bought in 1956 based on each of the following sources of pricing information: car-lot dealers or brokers, terminal quotat1ons, processors, truckers, locsl feeders, and home office. It was reported that 86.9 per cent of all grain purchased by the country elevators survejed in this study wos based on pricing information recelved from terminal quotations, and car-lot dealers or brokers. The most important single source was terminal quotations which accounted for an average of 65.6 per cent of the pricing information used as a base price by these country elevator operators for purchasing grain from farmers. Car-lot dealers or brokers were next in importance with 21.3 per cent. Home offices ranked third as source of pricing information by contributing an average of 5.3 per cent. Processors, truckers, and local feeders accounted for a total of 7.8 per cent of the pricing information. (Table VII.) 


\section{TABLE VII}

SOURCES OF PRICING INFORMATION AND PER CENT OF GRAIN THAT WAS BOUGHT BASED ON PRICE INFORMATION FROM EACH SOURCE, FIFTY-NINE COUNTRY ELEVATORS, MISSOURI, 1956

Source

Terminal Quotat1ons

Car-lot Dealers or Brokers

Home Office

Truckers

Local Feeders

Proces soors
(Per cent)

$$
65.6
$$

21.3

5.3

3.0

2.7

2.1

Total

100.0 
Changes in source of pricing information since 1946. Only one country elevator operator, out of the flfty-nine operators who were interviewed, reported a change in source of pricing information for the past ten year period. The operator who reported a change sa1d he was now recelving his pricing information from Kansas C1ty instead of from St. Louls. Two of the elevator operators had been in their present business too short a period of time to report any changes. Th1s would seem to 1ndicate that there have been no significant changes in the relative importance of the various terminal markets providing pricing information in the past ten years.

\section{COMPARISON OF GRAIN PRICES AMONG THE CROP REPORTING DISTRICTS IN MISSOURI}

The average prices per bushel recelved by farmers for corn, wheat, soybeans, and oats in each of the nine Crop Reporting D1stricts in M1ssour1 were obtained for the eleven year period 1946-1956. (Table VIII.) Average U. S. farm prices and average terminal market prices for these grains for the same period of time wore also secured. This was done for the purpose of discovering the differences in the level of prices at the farm and also to study the relationship between these farm prices and the terminal market prices for grain. 
ELEVEN YEAR AVERAGE PRICE PER BUSHEL RECEIVED BY FARMERS, AND AVERAGE PRICE FER BUSHEL PAID AT A TERMINAL MARKET FOR CORN, WHEAT, SOYBEANS, AND OATS;

1946 - 1956, INCLUSIVE*

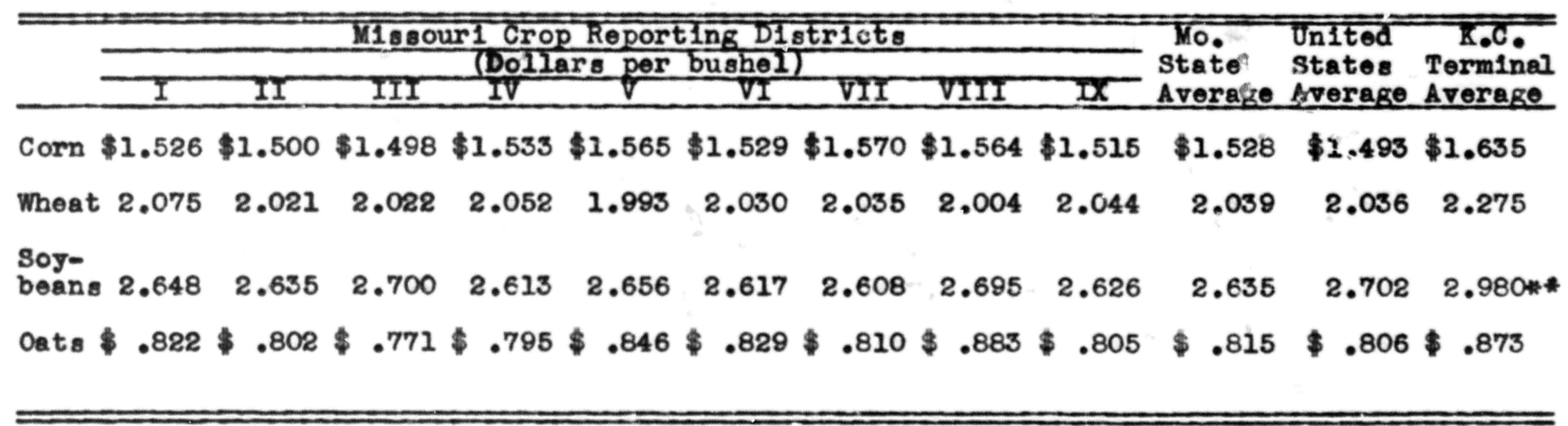

*Source: See Append1x TABIES I, II, III, and IV, pp. 81-84

* Ch1cago Terminal Market for Soybeans. 
The eleven year (1946-1956) average price recelved for corn by farmers in the nine Crop Reporting Districts in Missouri had a range of 7.2 cent per bushel between the high and low districts. (Table VIII.) The range extended from a low of $\$ 1,498$ per bushel for D1str1ct III (Northeast) to a h1gh of $\$ 1.57$ in D1strict VII (Southwest). The explanation for this price alferential may be the transportation costs involved in the shipment of corn and the fact that a relatively small amount of corn is produced In District VII. (Table IV, p. 11.) On the other hand, D1strict III produced considerably more corn than District VII, in adition to being located near the surplus corn producing area of Illinols. This would indicate that transportation costs for moving it to an area deficient in corn would have to be subtracted from the price pald to a farmer for his corn in D1strict III. The Mean Deviation in the average yearly prices per bushel recelved by farmers for corn during this eleven year period was approximately 2.2 cents among the nine Crop Reporting D1stricts in Missour1. The eleven year (1946-1956) average price received for wheat by farmers in the nine Crop Reporting Districts In Missouri had a range of 8.2 cents per bushel between the high and low Districts. (Table VIII.) The average price received extended from a low of $\$ 1.993$ per bushel in District V (Central) to a h1gh of $\$ 2.075$ in District I 
(Northwest). One possible explanation for this difference may be the fact that most of District I is located much nearer the Kansas C1ty terminal market than 18 D1strict $V$, which should result in lower transportation costs for wheat produced in District I. It was observed that three of the four Districts where the average farm price for wheat was highest were located on the western side of M1ssourl and bordering Kansas. Th1s western Great Plains area 1 s noted for 1ts large production of high quality hard red winter wheat, which may have some favorable effect on prices recelved for wheat from the western edge of M1ssour1. The Mean Deviation between the eleven yoar average prices recelved for wheat by farmers in the nine Crop Reporting Districts was found to be about 1.9 cents per bushel. The eleven year (1946-1956) average price recelved for oats by farmers in the nine Crop Reporting Districts had a range of 11.2 cents per bushel between the Districts. (Table VIII.) D1strict III (Northeast) had the lowest average price for the period w1tb 77.1 cents per bushel, whereas District VIII (South Central) farmers recelved the highest average price per bushel of 88.3 cents. However, in oat production District VIII ranked next to the lowest, but in livestock production it was somewhat more important. (See Appendix Table VI, p.86.) Th1s would indicate that there would be a good local demand for oats, as well as for 
other feed grains, that were produced in the area, and hence a favorable price situation for the growers. The Mean Deviation of the average prices per bushel recelved for oats by farmers was 2.4 cents among the nine Districts. The eleven year (1946-1956) average price recelved for soybeans by farmers in the nine M1ssourl Crop Reporting Districts had a range of 8.2 cents per bushel between the Districts. (Table VIII.) The lowest average farm price for the period was $\$ 2.608$ for District VII (Southwest), and the highest was $\$ 2.700$ for District III (Northeast). D1strict III borders the M1s81ssipp1 River, therefore has access to barge transportation. It is located relatively near the important soybean markets in Chicago and other points in Illinols. Th1s may help to account for the higher average price for D1strict III. On the other hand, D1strict VII is located in the southwest corner of the state, and more distant from any major soybean processing plants. There aren't enough soybeans produced in this area to attract soybean 011 m111s. The Mean Deviation of the average prices received for soybeans by farmers in the nine Crop Reporting Districts for this period was approximately 2.7 cents per bushel.

A comparison was also made between the eleven year (1946-1956) average price recelved by M1ssour1 farmers for corn, wheat, soybeans, and oats, and the average price 
recelved by farmers for these grains in the United States as a whole. (Table VIII.) It was found that M1ssour1 farmers received a slightly higher average price for the period, than the United States farm average, for corn, wheat, and oats. However, for soybeans 1t was noted that they recelved approximately 6.7 cents per bushel less than the average United States farm price for the period. There may be some association between this and the fact that M1ssourl has relatively few soybean oll mills as compared to other important soybean producing states such as IIlinols and Iowa. 1 Therefore, transportation costs involved in movirig the soybeans from M1ssourl farms to an 011 m111 may be greater.

Relationship of grain prices at the farm and at terminal markets. Terminal grain markots, such as those found In Kansas C1ty, St. Lou1s, and Ch1cago, and at other centers, are the most important sales outlet for country grain elevators.2 In this particular study of fifty-nine country grain elevators in M1ssour1, it was found that these elevators used terminal or sub-terminal agencies as sales outlets for about 72.4 per cent of the total grain sold.

IUnited States Department of Agriculture, The Yearbook of Agriculture: 1954: Market1ng (Washington: Government Printing off1ce, $\overline{1954}$ ), p. 457 .

${ }^{2}$ Kohls, 100. c1t. 
(Table XVII, p. 56.)

Comparisons were made of the average M1ssour1 farm price for the major grains and the average terminal price for these grains. The widest spread between farm and terminal price was for soybeans, and the most narrow spread was for oats. For the eloven year per1od (1946-56), terminal prices for soybeans averaged approximately 34.5 cents per bushel more than the farm price; 23.6 cents per bushel higher for wheat, 10.7 cents higher for corn, and 5.8 cents per bushel hagher for oats. (Table VIII.) The greatest difference between the farm and terminal price was for the grains used more for food (wheat and soybeans), and the smaller differences were for the feed grains (corn and oats). These differences in margins on the various kinds of grain may be due to the greater length of the marketing channel for wheat as compared to that for corn and oats; and to the greater risk of price fluctuation in the case of soybeans. It should also be pointed out that terminal prices are for a specific quality of grain, whereas the average farm price is for all grades and qualities. 
MARKETING MARGTNS FOR COUNTRY GRAIN ELEVATORS

Country grain elevator perform a service in grain marketing by furnishing the farmer a cash sales outlet for most of the grain which he sells. $0^{2}$ The remuneration which the elevator operator recelves for this service is the difference in price between what he pays to the grain producer and that price which he recelves for the grain when he, the elevator operator, in turn sells 1t. This price different1al 1s the gross margin recelved by the grain elevator operator for his merchandising function.

The elevator's gross margin, when referred to in th1s study, w1ll be the difference between the price the elevator pays for the grain and the price which 1t receives, less the cost of transportation to the elevator's sales outlet. Thus, if the elevator pays $\$ 1.80$ per bushel for wheat; sells 1t for $\$ 1.93$ per bushel, and the transportation costs are five cents, the elevator's gross margin is elght cents. Out of this gross margin the elevator operator pays for labor, other operating costs, and attempts to obtain a profit from the operation.

$$
I_{\text {Kohls, 10c. c1t. }}
$$


A decline in the price of grain between the time it is bought and sold may result in reducing the grose margin which the elevator operator attempts to maintain. Some elevators try to reduce the risk of $10 \mathrm{ss}$ due to price fluctuation by selling futures contracts in the amount of their cash purchases of the physical commodity. Th1s type of of setting transaction in the grain futures market is known as hedging. In a study of 150 country grain elevators in M1ssour1, Temple reported that about 33 per cent of the elevators practiced hedging ${ }^{2}$

I. PRESENT GROSS MARGINS FOR FIFTY-

NINE COUNTRY GRAIN ELEVATORS IN MISSOURI FOR GRAIN SHIPPED BY RAIL, BY TRUCK, AND SOLD LOCALLY

The grain elevator operators who were interviewed for this study were asked to give the gross margins per bushel which they normally obtalned for handing the various kinds of grain. Gross margins for grain sold locally, shipped by ra1l, and shipped by truck were 11sted separately. This information surmarized and is shown in Table IX. The average gross margin for grain sold locally was found to be from about one to four cents per bushel more than

2 Norman F. Temple, "Characteristics of Country Grain Elevators in Nissour1 as They Relate to Ora in Marketing" (unpublished Master's thes1s, Un1versity of M1ssour1, Columb1a, M1ssour1, 1955), p. 108. 
TABLE IX

GROSS MARGINS OF FIFTY-NINE COUNTRY ELEVATORS FOR GRAIN SHIPPED BY RAIL, TRUCK, AND SOLD LOCAILY, MISSOURI, 1956

\begin{tabular}{|c|c|c|c|c|c|c|c|c|c|}
\hline & & & & $\sqrt{c \theta n}$ & $g$ per b & ghelI & & & \\
\hline & & Corn & & & Wheat & & & 3orbean & \\
\hline & R211 & Truck & Locs & RaII & Truck & Local & Ra1I & Truck & 10081 \\
\hline Average & 7.2 & 7.7 & 8.8 & 7.6 & 7.4 & * & 8.2 & 7.5 & * \\
\hline Median & 8.0 & 8.0 & 10.0 & 8.0 & 7.0 & * & 8.0 & 7.0 & * \\
\hline Range & $4-10$ & $3-15$ & $3-15$ & $3-12$ & $3-13$ & * & $4-12$ & $2-13$ & * \\
\hline & & Oats & & & Barles & & Sol & hum Gra & \\
\hline & Ra1I & Truck & Local & Ra1I & Truck & Local & Ra11 & Truck & LocaI \\
\hline Average & 6.7 & 7.5 & 8.7 & 7.0 & * & 8.0 & 6.9 & 7.6 & 11.6 \\
\hline Median & 6.0 & 7.0 & 9.5 & 7.0 & \# & 8.5 & 7.0 & 7.0 & 13.0 \\
\hline Range & $4-15$ & $3-13$ & $3-18$ & 0 & * & $5-10$ & $5-10$ & $5-12$ & $5-17$ \\
\hline & & & & & & & & E & \\
\hline
\end{tabular}

* Indicates no sale of grain through this outlet was reported. 
the average gross margin for grain shipped by rail or truck. This would seem logical since grain sold locally would usually be in relatively small individual lots, and thus require more handling and labor per dollar of sale volume. For corn, the average gross margin for local sales was 8.8 cents per bushel; 7.7 cents for truck shipments, and 7.2 cents per bushel for rail shipments. The average gross margins for wheat was 7.6 cents per bushel for rall. shipments and 7.4 cents for truck shipments. Soybeans showed an average gross margin of 8.2 cents per bushel for rail shipments and 7.5 cents for those shipped by truck. No margins are shown for local sales of wheat and soybeans since practically none of these grains were reported to heve been sold locally. The average gross margin for oats sold locally was 8.7 cents per bushel; 7.5 cents for truck shipments and 6.7 cents per bushel for shipments by rail. For barley, the average gross margin was 8.0 cents per bushel on local sales, and 7.0 cents per bushel for rail shipments. No truck shipments were reported. The average gross margin reported for sorghum grains was 11.6 cents per bushel for that which was sold locally; 7.6 cents per bushel for truck shipments, and 6.9 cents per bushel for rail shipments. Tho Medien gross margin for rail shipments of corn, wheat, and soybeans was 8.0 cents for each of them. Barley and sorghum grains each had 7.0 cents per bushel as the 
Median gross margin for shipments by rail. The median gross margin for oats shipped by ra1l was 6.0 cents per bushel. For truck shipments, of wheat, soybeans, oats and sorghum gralns the Median gross margin was 7.0 cents per bushel. The Median gross margin for corn was 8.0 cents per bushel.

The Median, as well as the average, gross margin was highor for grain sold locally than for grain shipped out by rall or truck for all the grains that were sold locally. The Median gross margin for local sales of corn was 10.0 cents per bushel, 9.5 cents for oats, 13.0 cents for sorghum grains, and 8.5 cents per bushel for barley.

The range in gross margins for rail shipments was from 4-10 cents per bushel for corn, 3-12 cents for wheat, 4-12 cents for soybeans, 4-15 cents for oats, and 5-10 cents per bushel for sorghum grains. (See F1gure 2.) Seven cents per bushel was the only amount given as the gross margin for rall shlpments of barley. Only two elevators reported rall shipments of this grain.

The range in gross margins reported for local sales of grain were equal to or greater than the ranges reported for grain shipments by truck or by rail for each kind of grain that was sold locally. The widest range in grose margins was from $3-18$ cents per bushel which was reported for oqts. (Table IX.) 


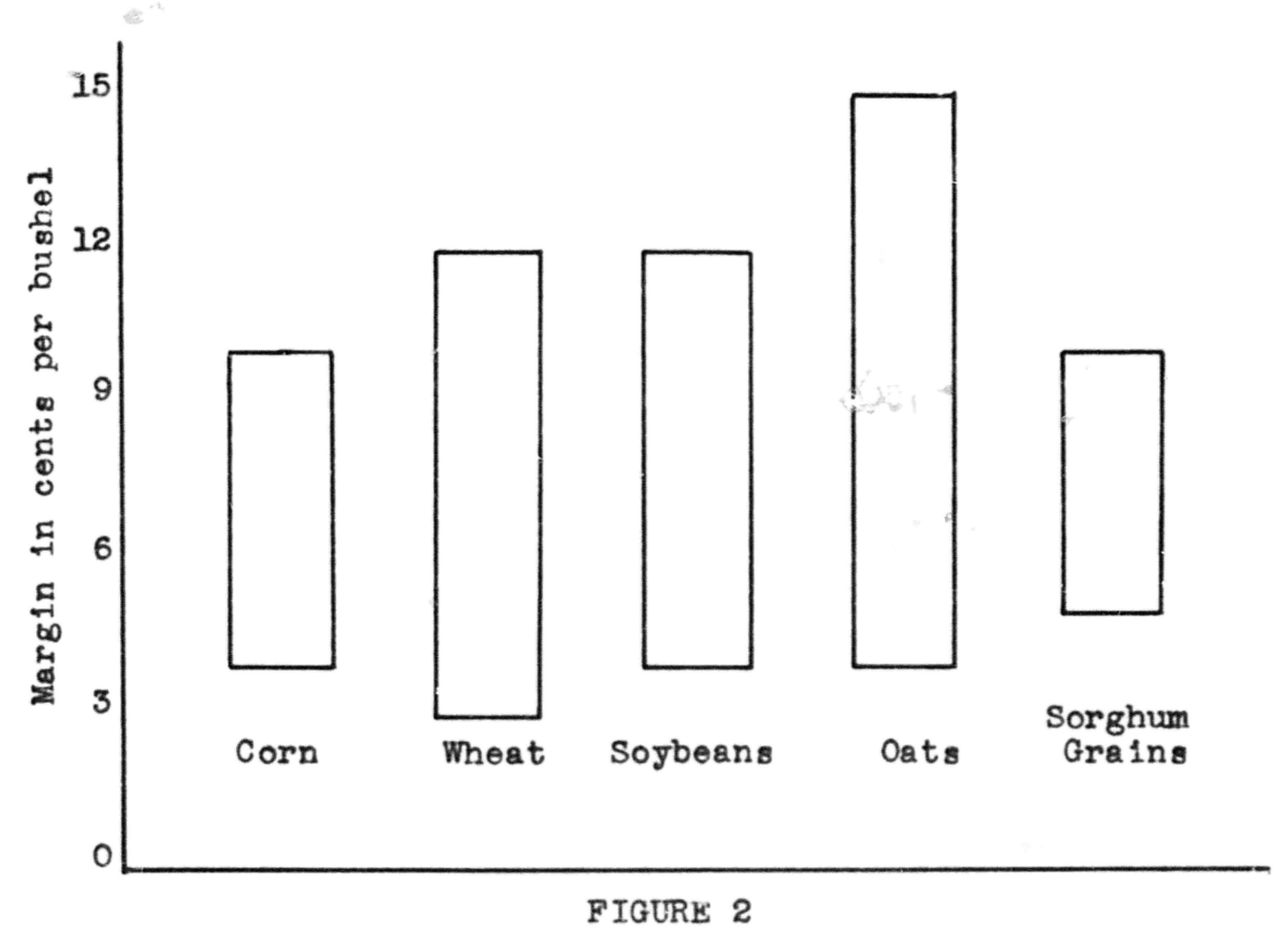

RANGE IN MARGINS ON RAIL SHIPMENTS OF FIVE GRAINS, FIFTY-NINE COUNTRY ELEVATORS, MISSOURI, 1956 
For truck shipments, the range in gross margins per bushel was from one to six cents greater than those for shipments by rail for each kind of grain except oats. For oats, the range in gross margins was one cent per bushel more for rais than for truck shipments.

The average gross margins, for the elevators as a whole, were slightly higher for truck shipments of corn, oats, and sorghum grains than for rail shipments of these grains. The reverse was true in the case of wheat and soybeans. This differentiation did not exist for individual elevators, however. In comparing the margins for individual elevators 1t was noted that when a difference existed between margins on grain shipped by truck, and that which was shipped by rail, this difference existed for each kind of grain handled. That is, 1t wasn't reported that a larger margin was obtained on one kind of grain if it was shipped by truck, and a larger margin on another kind of grain if 1t was shlpped by ra1l.

Forty-three of the fifty-nine elevator operators who were interviewed reported that their margins were the same for both rail and truck shipments of grain. Nost of the differences which did exlst were reported to be two cents or Iess per bushel.

Comparison of gross margins for large and small elevators. A comparison of gross margins for large and 
small elevators was made to discover whether or not large volume elevators, because of their large volume, operated on lower margins. The results are shown in Table $X$. In this sample, the large elevators had average gross margins of from .I cent to 1.5 cents per bushel greater than the small elevators for corn, wheat, soybeans, and barley. On the other hand, small elevators had average gross margins of .3 cent and 1.2 cents per bushel more than the large elevators for sorghum grains and oats, respectively. The results of this comparison do not seem to substantiate the 1dea that elevators with large volume operate with lower margins, or that because of thoir lower margin they get more business and therefore become large volume elevatore.

Compar1son of gross margins among the three types of firm ownersin. The results of a comparison of gross margins for the different types of firm ownersip are given in Table XI. The highest average gross margins reported for comn and oats were on local sales by private flrms which operated several elevators. For wheat, the highest average gross margin was for rail shipments made by firms operated as cooperatives. The ilghest average gross margin for soybeans was reported by private fims operating a single elevator, and was for rail shipments.

Both the highest and lowest average gross margin 
TABIE X COMPARISON OF THE GROSS MARGINS OF LARGE ELEVATORS AND SMALL ELEVATORS, BY KIND OF GRAIN, FIFTY-NINE COUNTRY ELEVATORS, MISSOURI, 1956

\begin{tabular}{|c|c|c|c|c|c|c|}
\hline Grain & \multicolumn{3}{|c|}{ Large Elevators } & \multicolumn{3}{|c|}{ Sma 11 Elevators } \\
\hline Corn & 8.1 & 8.0 & $4-13$ & 8.0 & 7.5 & $3-15$ \\
\hline Wheat & 8.0 & 8.0 & $3-13$ & 7.0 & 6.0 & $3-12$ \\
\hline Soybean 8 & 8.4 & 8.0 & $2-13$ & 6.9 & 7.0 & $3-12$ \\
\hline Oat: & 7.5 & 7.0 & $4-23$ & 8.7 & 8.0 & $3-18$ \\
\hline Barley & 7.7 & 7.0 & $5-10$ & 6.7 & 5.0 & $5-10$ \\
\hline Sorghum Grains & 8.1 & 7.0 & $5-17$ & 8.4 & 8.0 & $5-13$ \\
\hline
\end{tabular}




\section{TABLE XI}

GROSS MARGINS OF FIFTY-NINE COUNTRY ELEVATORS, GROUPED ACCORDING TO TYPE OF

FIRM OWNERSHIP, FOR RAIL SHIPMENTS, TRUCK SHIPMENTS,

AND LOCAL SALES OF GRAIN, MISSOURI, 1956

(cents per bushel)

\begin{tabular}{|c|c|c|c|c|c|c|c|c|c|c|}
\hline \multirow{2}{*}{$=$} & \multicolumn{3}{|c|}{ Corn } & \multicolumn{2}{|c|}{ Wheat } & \multicolumn{2}{|c|}{ Sojbeans } & \multicolumn{3}{|c|}{ Oats } \\
\hline & Ra11 & rruck & Local & $\operatorname{Ra11}$ & Truck & Ra11 & Truck & Ra1I & Truck & Local \\
\hline & & & & & & & & & & \\
\hline $\begin{array}{c}\text { Cooperatives: } \\
\text { Average } \\
\text { Median } \\
\text { Range }\end{array}$ & $\begin{array}{l}7.3 \\
8.0 \\
5-8\end{array}$ & $\begin{array}{l}8.9 \\
9.0 \\
5-12\end{array}$ & $\begin{array}{l}8 \cdot 7 \\
8 \cdot 0 \\
5-12\end{array}$ & $\begin{array}{l}8 \cdot 1 \\
8 \cdot 0 \\
5-12\end{array}$ & $\begin{array}{l}8 \cdot 0 \\
8 \cdot 0 \\
6-10\end{array}$ & $\begin{array}{l}7.7 \\
8.0 \\
4-11\end{array}$ & $\begin{array}{c}8.7 \\
10 \cdot 0 \\
6-10\end{array}$ & $\begin{array}{l}6.0 \\
6.0 \\
4-8\end{array}$ & $\begin{array}{c}9.0 \\
10 \cdot 0 \\
6-12\end{array}$ & $\begin{array}{l}8 \cdot 2 \\
9 \cdot 0 \\
5-10\end{array}$ \\
\hline $\begin{array}{l}\text { Private: } \\
\text { Firm Operating }\end{array}$ & $Q$ & & & & & & & a & & \\
\hline $\begin{array}{l}\text { Average } \\
\text { Median } \\
\text { Range }\end{array}$ & $\begin{array}{l}6.1 \\
7.0 \\
4-8\end{array}$ & $\begin{array}{l}7.3 \\
6.5 \\
4-15\end{array}$ & $\begin{array}{c}9 \cdot 1 \\
10 \cdot 0 \\
4-15\end{array}$ & $\begin{array}{l}7 \cdot 0 \\
7 \cdot 0 \\
3-10\end{array}$ & $\begin{array}{l}7 \cdot 6 \\
7 \cdot 5 \\
6-10\end{array}$ & $\begin{array}{l}7 \cdot 8 \\
8 \cdot 0 \\
5-10\end{array}$ & $\begin{array}{l}7 \cdot 5 \\
7 \cdot 0 \\
6-10\end{array}$ & $\begin{array}{l}6.0 \\
6.0 \\
4-8\end{array}$ & $\begin{array}{l}5 \cdot 8 \\
5 \cdot 5 \\
5-7\end{array}$ & $\begin{array}{l}10 \cdot 2 \\
10.0 \\
5-18\end{array}$ \\
\hline Private: & & & & & & & & & & \\
\hline $\begin{array}{l}\text { Average } \\
\text { Median } \\
\text { Range }\end{array}$ & $\begin{array}{l}7.8 \\
8.0 \\
4-10\end{array}$ & $\begin{array}{l}7 \cdot 1 \\
7 \cdot 0 \\
3-13\end{array}$ & $\begin{array}{c}8 \cdot 8 \\
10 \cdot 0 \\
3-15\end{array}$ & $\begin{array}{l}7.8 \\
8.0 \\
4-11\end{array}$ & $\begin{array}{l}7 \cdot 1 \\
6 \cdot 5 \\
3-13\end{array}$ & $\begin{array}{c}8.8 \\
10.0 \\
5-12\end{array}$ & $\begin{array}{l}7 \cdot 3 \\
7 \cdot 5 \\
2-13\end{array}$ & $\begin{array}{l}7.8 \\
7.0 \\
5-15\end{array}$ & $\begin{array}{l}7.0 \\
6.0 \\
3-7\end{array}$ & $\begin{array}{l}8.5 \\
8.0 \\
3-15\end{array}$ \\
\hline
\end{tabular}


reported for any kind of grain was for oats, and they were each reported by private firms operating several plants. The lowest average gross margin was 5.8 cents per bushel for truck shipments, and the highest average gross margin was 10.2 cents per bushel for local. sales of oats.

It should be pointed out that the amounts reported for gross margins were given in answer to the question of what their margins usually were on the varlous kinds of grain and for various sales outlets. The differences in margins could be due to differences in buying price, or a difference in selling price, or both. Pherefore, it cannot be said that particular types of firms made larger margins because they paid the farmer less for his grain. They could have paid a fully competitive price for the farmer's grain and then, due to an excellent sales outlet, obtained a higher selling price, and thereby a higher margin.

Comparison of gross margins among the Missouri Crop Reporting D1stricts. A summary was made of the gross margins which country grain elevators usually obtained on the four major grains in each of the nine Crop Reporting Districts in Missouri. The gross margins were listed separately for grain shipped by rail, shipped by truck, or sold locally. This information is presented in Tables XII, $X I I I$, and XIV. 
Figure 3 shows that the average gross margin on corn shipped by rail ranged from a low of 5.7 cents per bushel for District I (Northwest), and District VI (East), to a high of 10.0 cents per bushel in District IX (Southesst). The lowest average gross margins for rail shipments of wheat, soybeans, and oats were reported for District VII (Southwest). These margins, per bushel, were 5.3 cents for wheat, 6.0 cents for soybeans, and 5.0 cents for oats. District IX (Southeast) had the highest average gross margins on shipments by rail for corn, wheat, soybeans, and oats. These gross margins averaged 10.0 cents, 8.8 cents, 10.2 cents, and 15.0 cents per bushel, respectively. However, it should be pointed out that for rail shipments of corn and oats in District VII, and for oats in District IX, the above gross margins may or may not be representative for these Districts, because only one flrm, in each case, reported rail shipments of these grains. Therefore, a much larger sample would have bo baken befors any definite conclusions could be drawn as to the average gross margins on these grains for the elevator population in these Districts. However, it does appear that rall shipment is used for these grains by relatively few elevators in Districts VII and IX.

The gross margins on grain shipped by truck are shown in Table XIII, pe 43. The average gross margin for all the elevators for corn shipped by truck was 7.7 cents per 


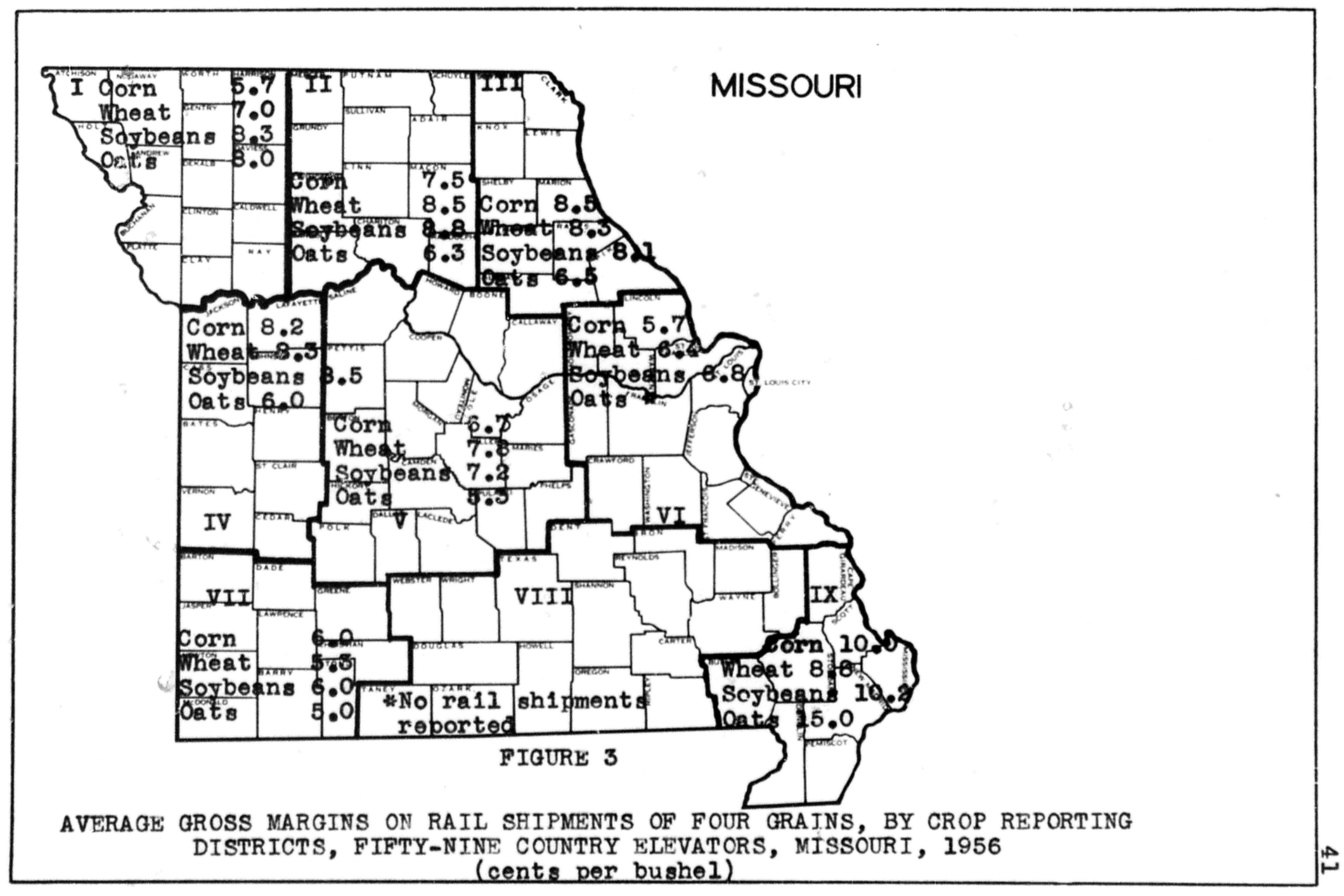


TABLE XII

GROSS MARGINS OF FIFTY-NINE COUNTRY ELEVATORS FOR GRAIN SHIPPED BY RAIL, BY CROP REPORTING DISTRICTS, MISSOURI, 1956 (cents per bushel)

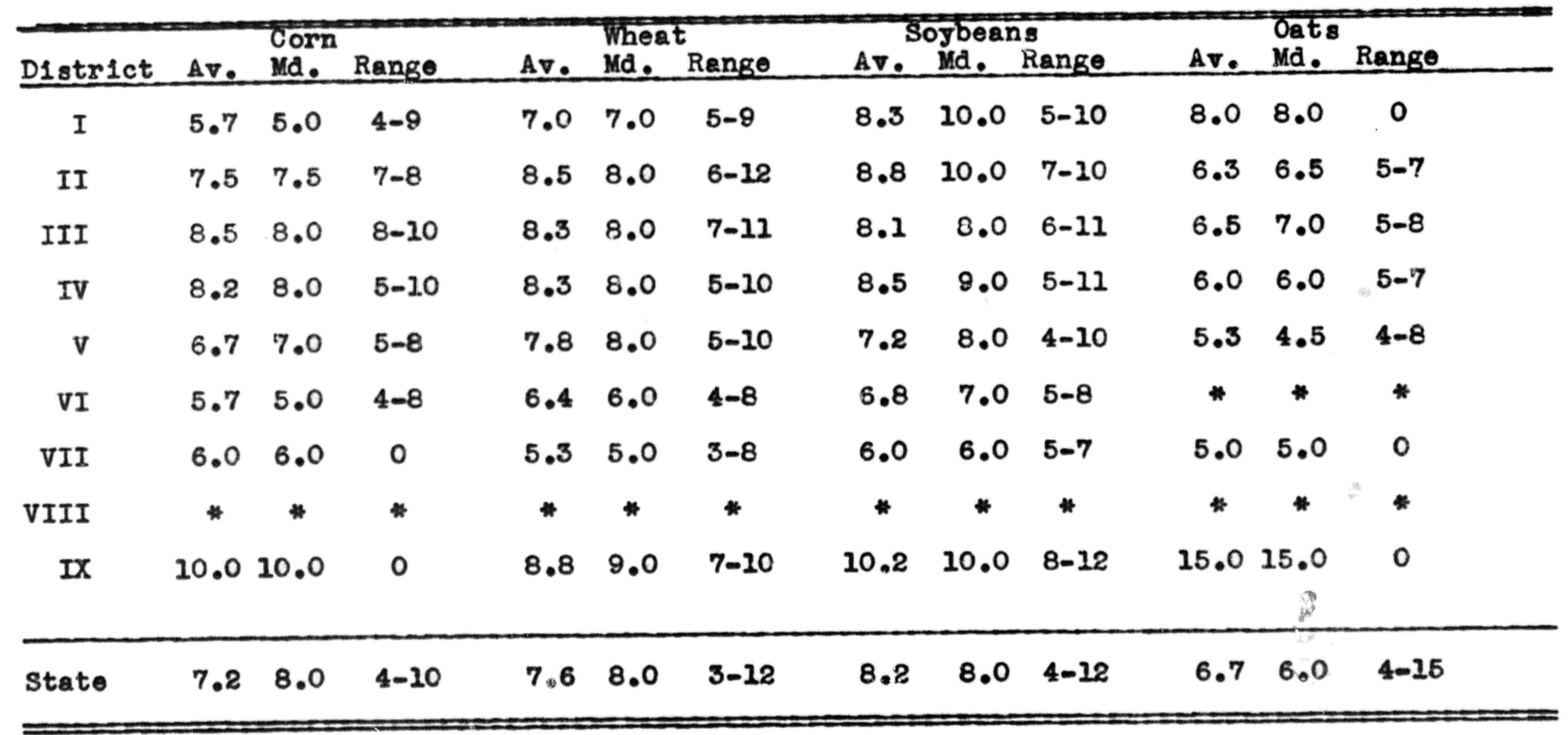

*Indicates no rail shipments were reported for this grain. 
TABLE XIII

GROSS MARGINS OF FIFTY-NINE COUNTRY ELEVATORS FOR GRAIN SHIPPED BY TRUCK, BY CROP REPORTING DISTRICTS, MISSOURI, 1956

(cents per bushel)

\begin{tabular}{|c|c|c|c|c|c|c|c|c|c|c|c|c|}
\hline \multirow[b]{2}{*}{ District } & \multicolumn{3}{|c|}{ Corn } & \multicolumn{3}{|c|}{ Wheat } & \multicolumn{3}{|c|}{ Oats } & \multicolumn{3}{|c|}{ Sorbeans } \\
\hline & Av. & Ma. & Range & Av. & Ma. & Range & Av. & Ma. & Range & Avo & Ma. & Range \\
\hline$I$ & 4.8 & 5.0 & $4-5$ & 7.8 & 8.0 & $5-10$ & 5.0 & 5.0 & 0 & 7.5 & 7.5 & $5-10$ \\
\hline II & 8.3 & 8.0 & $7-10$ & 7.3 & 8.0 & $6-8$ & 7.3 & 6.5 & $6-10$ & 8.3 & 8.0 & $7-10$ \\
\hline III & 11.0 & 11.0 & $10-12$ & 7.0 & 6.0 & $6-10$ & 11.0 & 11.0 & $10-12$ & 7.0 & 6.0 & $6-10$ \\
\hline IV & 7.0 & 6.5 & $5-10$ & 5.0 & 5.0 & 0 & 6.3 & 7.0 & $5-7$ & 4.5 & 4.5 & $2-7$ \\
\hline $\mathbf{v}$ & 8.0 & 8.0 & 0 & 8.0 & 8.0 & $6-10$ & 5.0 & 5.0 & 0 & 6.0 & 6.0 & 0 \\
\hline VI & 8.3 & 7.5 & $5-13$ & 8.5 & 8.0 & $5-13$ & 13.0 & 13.0 & 0 & 8.7 & 8.0 & $5-13$ \\
\hline VII & 7.0 & 7.0 & $6-8$ & * & * & * & * & * & * & 7.0 & 7.0 & 0 \\
\hline VIII & 15.0 & 15.0 & 0 & $*$ & * & * & * & * & * & * & * & * \\
\hline IX & 6.5 & 6.5 & $3-10$ & 7.0 & 7.5 & $3-10$ & 3.0 & 3.0 & 0 & 8.4 & 10.0 & $3-11$ \\
\hline State & 7.7 & 8.0 & $3-15$ & 7.4 & 7.0 & $3-13$ & 7.5 & 7.0 & $3-13$ & 7.5 & 7.0 & $2-13$ \\
\hline
\end{tabular}

*Indicates no truck shipments were reported for this grain. 
bushel. However, there was a rather wide variation among the various Crop Reporting Districts. The lowest average gross margin for corn was 4.8 cents per bushel in District I (Northwest), which is the most important corn producing District in the state. The highest gross margin for corn was 15.0 cents per bushel which was reported by one elevator in District VIII (South Central). Th1s is a corn deficit area, and has comparatively few grain elevators, because a relatively small amount of any grain is produced in this District. (See Table IV, p. II.)

For wheat, the average gross margins on truck shipments were falrly unfform. The average gross margin for all elevators was 7.4 cents per bushel. The lowest average gross margin was 5.0 cents per bushel for District IV (West), and the highest was 8.5 cents per bushel for D1str1ct VI (Eest). No truck sh1pments of wheat were reported by the elevators interviewed in Districts VII and VIII.

The average gross margin on oats shipped by truck for all of the country grain elevators that were included in this study was 7.5 cents per bushel. However, there was a rather wide range between the highest and the lowest average gross margins for the Crop Reporting Districts within the state. The lowest gross margin was 3.0 cents per bushel which was reported by one elevator in District IX, and the 
highest margin was 13.0 cents per bushel reported by an elevator in District VI. In Districts VII (Southwest) and VIII (South Central) no elevators reported shipment of oats by truc In Districts I, V, VI, and IX, only one of the elevators in each District reported truck shipments for oats. The information received from the elevator operators that were interviewed for this study indicated that approximately 79.6 per cent of the oats which country elevators buy are re-sold locally. (Table XVI, p. 52.) Th1s would leave a relatively small amount for disposition by truck and reil shipments.

For soybeans, the average gross margin, for all of the country elevators that were surveyed was 7.5 cents per bushel on trucked shipments. Within the Crop Reporting Districts, the average gross margins ranged from a low of 4.5 cents per bushel for District IV (West), to a high of 8.7 cents per bushel for District VI (East). However, in District IV only two elevators reported truck shipments of soybeans. It is therefcre felt that before definite conclisions could be reached concerning the relative amounts for the average gross margins between Districts that a much larger sample of elevators would need to be obtained. Teble XIV shows the average gross margins reported 3 countey grain elevators for corn and Coats sold locally. The average gross margins for all elevators in this study was 8.8 cents per bushel on corn, and 8.7 cents per bushel 
TABLE XIV

GROSS MARGINS OF FIFTY-NINE COUNTRY ELEVATORS FOR GRAIN SOLD LOCALLY; BY CROP REPORTING DISTRICTS,

MISSOURI, 1956

(cents per bushel)

\begin{tabular}{|c|c|c|c|c|c|c|}
\hline \multirow{2}{*}{ D1strict } & \multicolumn{3}{|c|}{ Corn } & \multicolumn{3}{|c|}{ Oats } \\
\hline & Av. & IId. & Range & $\overline{\text { A. }}$ & Ma. & Range \\
\hline I & 6.3 & 5.5 & $4-10$ & 5.5 & 5.5 & $5-6$ \\
\hline II & 9.2 & 10.0 & $8-10$ & 8.2 & 8.0 & $6-80$ \\
\hline III & 11.4 & 10.0 & $10-15$ & 11.0 & 10.0 & $10-15$ \\
\hline IV & 8.0 & 9.0 & $5-10$ & 8.7 & 9.0 & $7-10$ \\
\hline $\mathbf{v}$ & 8.8 & 10.0 & $5-10$ & 9.0 & 9.0 & $8-10$ \\
\hline VI & 8.7 & 8.0 & $8-10$ & 8.5 & 8.5 & $7-10$ \\
\hline VII & 8.4 & 8.0 & $6-10$ & 6.5 & 5.5 & $3-10$ \\
\hline VIII & 16.0 & 15.0 & 0 & 18.0 & 18.0 & 0 \\
\hline$I X$ & 7.7 & 5.0 & $3-15$ & 9.0 & 9.0 & $3-15$ \\
\hline state & 8.8 & 10.0 & $3-15$ & 8.7 & 9.5 & $3-18$ \\
\hline
\end{tabular}


on oats. The average gross margins on corn for the varlous Crop Reporting Districts ranged from a low of $62^{2}$ cents per bushel for District I (Northwest) to high of 15.0 cents per bushel in District VIII (South Central). These same Districts had the lowest and highest average gross margins for oats sold locally; with a low of 5.5 cents per bushel In District $I$, and a high of 13.0 cents per bushel for District VIII. However, there are relatively few grain elevators in District VIII ana only one elevator in this district furnished information for th1s study. Th1s limits the formulation of definite conclusions concerning gross margins in D1strict VIII. It might also be pointed out that District VIII produces a small percentage of the corn and oats grown in M1ssour1 whereas District I ranks high in the production of each of these gxains. (See Table IIf, p. 8.)

Changes in gross margins since 1946. The fifty-nine country grain elevator operators who were interviewed for this study were asked to give the changes which had occured In their gross margins for each class of grain since 1946. The results are shown in Fable XV. For corn, 40 elevator operators reported that there had been no changes in their gross margins since 1946, 7 reported that their gross margins had declined moresthan 2 cents per bushel, and 3 indicated that their gross margins had declined from 1.1 cents to 2.0 cents per bushel in the previous ten year period. 
Wheat and soybeans were the only grains for which any elevator operator reported an increase in gross margin during the past ten years. For each of these two grains, the elevator operator indicated an increase 1 gross nargin of from 1.1 cents to 2.0 cents per bushel. However, the majority of the elevator operators interviewed for this study reported that there had been no changes in their gross margins on the various classes of grain since 1946. Those reporting a decrease in gross margine gave increased competition as the principal reason. 
TABLE XV

CHANGES IN GROSS MARGINS ON GRAIN SINCE 1946,

FIFTY NINE COUNTRY ELEVATORS,

MISSOURI, 1956

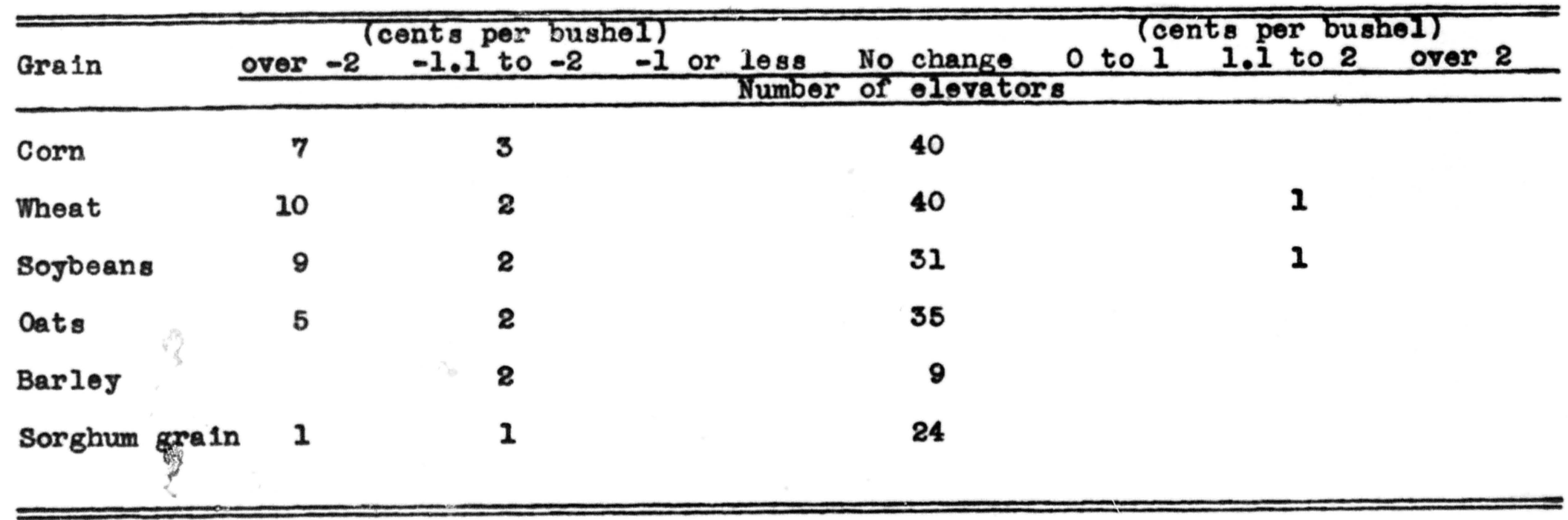




\section{CHAPTER IV}

\section{METHODS OF SALE FOR COUNTRY GRAIN ELEVATORS}

Country grain elevator operators have many sales outjests for their grain. They sell some of 1t to local Iivestock feeders, sh1p part of 1t to feed manufacturers, millers, processors, and to livestock feeders in deflc1t producing areas. However, most of the grain handled by country grain elevators goes to terminal markets. 1 Kohls states that country elevator operators sell about 75 per cent of their grain purchases to terminal elevators. ${ }^{2}$ In this particular study of fifty-nine country grain elevators In Missour1, 1t was reported that these elevators used terminal or sub-terminal agencies as sales outlets for approximately 72.4 per cent of the total grain sold (Table XVI, p. 52.)

Terminal markets provide market quotations, weighing and inspection services, drying and storage facilities, services of commission merchants, and services of financing, Insurance, and forwarding agencies. Farmers, country elevators, or others who wish to ship grain to a terminal market may either sell their grain to a cash grain firm,

IThe Yearbook of Agriculture: 1954. Marketing, op. c1t., p. 408 .

$$
2_{\text {Kohls, 10c. c1t. }}
$$


consign it to the market for sale by a commission merchant, or to a terminal elevator or warehouse for storage. However, relatively little grain is sold direct from the rarm to terminal markets. 3 It usually is sold to the country grain elevator first.

\section{SAIES OUTLETS}

The fifty-nine Missourl country elevator operators who were interviewed for this study were asked to estimate the number of bushels of each kind of grain which they had sold through the various sales outlets during the past year. This information is shown in Table XVI.

It was found that there was considerable difference in the type of sales outlets used most for the different kinds of grain. For example, Local Sales were reported to be the most important sales outlet for oats and barley, somewhat less important for corn and sorghum grains, and of practically no importance for wheat or soybeans. Local Sales provided the outlet for approximately 10.9 por cent of the total volume of grain handled by these elevators. For corn, terminal or sub-terminal elevators and the varlous agencles connected with them, accounted for approximately 61.0 per cent of the total amount sold by the

$$
3 \text { Temple, op. c1t., p. } 62 .
$$




\section{TABLE XVI}

PER CENT OF TOTAL VOLUME OF EACH KIND OF GRAIN SOLD GOING THROUGH

EACH SALES OUTLET, FIFTY-NINE COUNTRY ELEVATORS,

MISSOURI, 1956

\begin{tabular}{|c|c|c|c|c|c|c|}
\hline \multirow[b]{2}{*}{ SAIES OUTLET } & \multirow[b]{2}{*}{ Corn } & \multicolumn{5}{|c|}{ Per cent } \\
\hline & & Wheat & Soybeans & Oats & Barley & Sorghum grain \\
\hline IOCAL SALES & 24.1 & * & * & 79.6 & 84.0 & 10.1 \\
\hline $\begin{array}{l}\text { RAIL SHIPMENTS: } \\
\text { Consigned to terminals } \\
\text { Sold to terminal merchandisers } \\
\text { Sold to car-lot dealers: } \\
\text { At terminals } \\
\text { At interior points } \\
\text { sold direct to processors }\end{array}$ & $\begin{array}{r}26.8 \\
8.9 \\
5.4 \\
.6 \\
2.1\end{array}$ & $\begin{array}{c}56.0 \\
16.4 \\
11.6 \\
1.3\end{array}$ & $\begin{array}{c}25.5 \\
12.2 \\
11.2 \\
7.6\end{array}$ & $\begin{array}{c}2.3 \\
9.3 \\
2.7 \\
* \\
.6\end{array}$ & $\begin{array}{c}* \\
* \\
13.6 \\
* \\
2.4\end{array}$ & $\begin{array}{r}44.5 \\
30.7 \\
* \\
* \\
.3\end{array}$ \\
\hline $\begin{array}{l}\text { TRUCK SHIPMBNTS: } \\
\text { Sold to truckers at elevator } \\
\text { Sold direct to term.or sub-term.elev } \\
\text { Sold direct to processors } \\
\text { Sold through dealers to: } \\
\text { Terminal and sub-terminal elevator } \\
\text { Processors }\end{array}$ & $\begin{array}{r}11.7 \\
2.0 \\
.5 \\
1.4 \\
*\end{array}$ & $\begin{array}{l}.03 \\
8.4 \\
1.8 \\
* \\
*\end{array}$ & $\begin{array}{r}\text { \#.0 } \\
6.2 \\
1.1 \\
11.0\end{array}$ & $\begin{array}{c}3.9 \\
.2 \\
* \\
1.4 \\
*\end{array}$ & $\begin{array}{l}* \\
* \\
* \\
* \\
*\end{array}$ & $\begin{array}{c}8.1 \\
1.5 \\
* \\
1.4 \\
1.4\end{array}$ \\
\hline $\begin{array}{l}\text { BARGE SHIPMENTS: } \\
\text { Direct to exporter } \\
\text { To terminal merchand1 ser }\end{array}$ & 16.5 & $\begin{array}{l}1.5 \\
2.7\end{array}$ & $\begin{array}{r}15.3 \\
3.9\end{array}$ & * & * & * \\
\hline Total & 100.0 & 100.0 & 100.0 & 100.0 & 100.0 & 100.0 \\
\hline
\end{tabular}

*Indicates that no grain was reported for that sales outlet. 
elevator operators who were interviewed for this study. Local sales represented about 24.1 per cent of the corn sales. Truckers bought about 11.7 per cent, processors bought 2.6 per cent, and car-lot dealers that were not located at the terminal markets were the sales outlet for about . 6 per cent of the corn handled by these country grain elevators.

The most important single sales outlet for wheat was rail shipments consigned to terminals. Altogether, terminal or sub-terminal elevator and their agencles provided the sales outlet for about 95.1 per cent of the wheat sold by the elevator operators included in this study. Sales to processors, exporters, and truckers accounted for a total of 4.9 per cent.

Ra1l shipments consigned to terminals was the most important single sales outlet for soybeans, which was also true for corn and wheat. Terminal or sub-terminal elevators and their agencies proviced these elevators the sales outlet for approximately 59.9 per cent of their soybeans. About 24.8 per cent were sold to processors, and approximately 15.3 per cent were reported to have been sold direct to exporters.

Oats and barley were the only grains for which it was reported that Local Sales were the most important sales outlet. These country elevator operators indicated that 
about 79.6 per cent of their oats, and 84.0 per cent of their barley was re-sold locally.

For sorghum grains, terminal or sub-terminal elevators and their agencies accounted for approximately 80.1 per cent of the total amount sold by these eleyaters. They reported that Local Sales accounted for about 10.1 per cent of their sales of sorghum grains, and the remainder was sold to truckers and processors.

The per cent of all grain handled that went through each sales outlet wa detormined for the fifty-nine Misouri country grain elevators included in this study. This information is shown in Figure 4. It was determined that approximately 10.9 per cent of these elevators' total volume of grain was disposed of through Local Sales. Of the individual classes of grain, oats and barley had a much higher per cent for Local Sales, however, these two grains and sorghum grains made up only a smalj. percentage of the entire volume of grain handled. Terminal and sub-terminal elevators and their agencies provided sales outlets for an average of about 72.4 per cent of all grain sold by the country elevator operators that were interviewed for tinis study. But for some of the individual classes of grain, such as wheat, for example, the percentage going through terminal agencies was much greater than thise Processors bought approximately 8.1 per cent of the grain sold by these country grain elevator operators, and the remainder was sold 


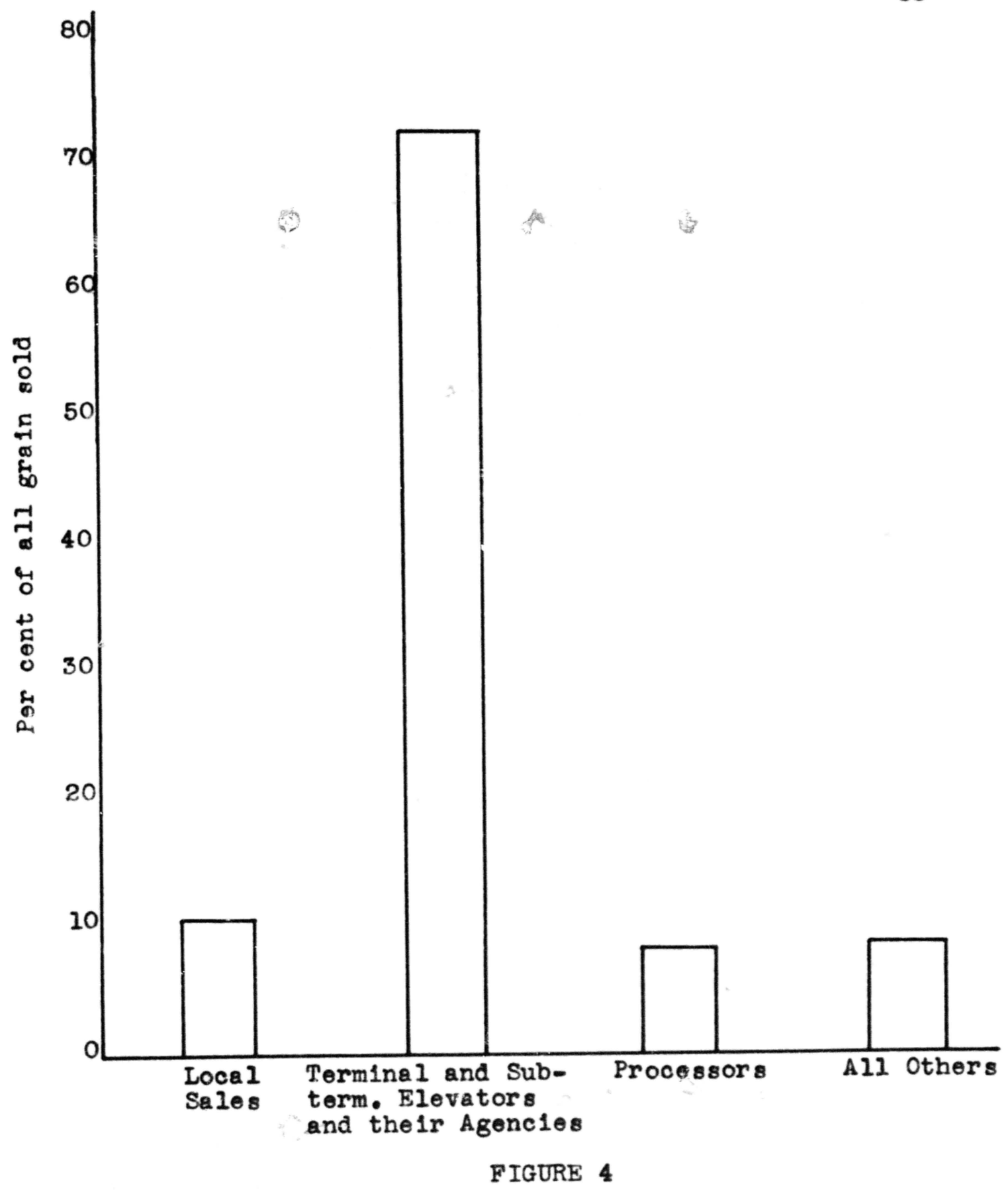

SALE OUTLETS EXPRESSED AS A PER CENT OF THE TOTAL VOLUME OF ALI GRAIN SOLD, FIFTYNINE COUNTRY ELEVATORS, MISSOURI, 1956 
TABLE XVII

PER CENT OF ALI GRAIN SOLD THAT WENT TEROUGH EACH

SALES OUTLET, FIFTY-NINE COUNTRY ELEVATORS,

MISSOURI, 1956

Seles outlet

(Per cent)

Local sales

10.9

Ra1l Shipments:

Consigned to terminals

Sold to terminal merchandizers

37.1

Sold to car-lot dealers:

At torminals

At inter10r point:

Sold direct to processors

13.1

9.0

$\cdot 2$

3.1

Truck Sh1pments:

Sold to trucker at elevator

sold direct to term. or sub-terminal elevator

Sold direct to processors

4.1

5.3

2.3

Sold through dealers to:

Terminal and ab-terminal elevator

Processors

.8

Barge Sh1pments:

Direct to exporter

To terminal Merchandisers

4.3

7.1

Total

100.0 
to truckers, car-lot dealers not located at the terminal markets, and to exporters.

\section{TRANSPORTATION METHODS USED}

The fifty-nine Missour1 country grain elevator operators who were interviewed for this study were asked to break down their grain sales for the past year into the types of transportation ut1lized. Th1s information is presented in Table XVIII.

Ra1l shipment wes the most important method of transportation used for all grains except oats and barley. Most of these two grains were sold locally, which would result in most instances of the livestock feeder hauling the grain from the elevator out to the farm himself. Of the individur. 1 kinds of grain, wheat had the highest percentage of ra11 shipments. It was indicated that approximately 85.3 per cent of the wheat sold by these elevator operators was shlpped by rail.

of the total volume of grain handled approximately 10.9 per cent was sold locally, 62.5 per cent was shipped by rail, 15.2 per cont was shipped by truck, and 11.4 per cent was shipped by barge.

At the bottom of Table XVIII, is shown the per cent thet each kind of grain was of the total volume of all grain handled by these fifty-nine country elevators. Wheat accounted for approximately 38.3 per cent of all grain 
TABIE XVIII

PER CENT OF EACH KIND OF GRAIN GOING THKOUGH EACH OUTLET; PEF CENT OF ALL GRAIN GOING THROUGH EACH OUTLET; AND THE PER CENT EACH GRAIN WAS OF TOTAL VOLUME OF ALL GRAIN SOLD, FIFTY-NINE COUNTRY ELEVATORS, MISSOURI, 1956

\begin{tabular}{|c|c|c|c|c|c|c|c|}
\hline Outlet & Corn & Whert & Sorbeans & Oats & $\begin{array}{l}\text { Sorghum } \\
\text { Grain }\end{array}$ & Barler & $\begin{array}{l}\text { Averaso for } \\
\text { A11 Grain }\end{array}$ \\
\hline Local Salos & 24.1 & - & - & 79.6 & 10.1 & 83.8 & 10.9 \\
\hline Ra11 Sh1pment & 43.8 & 85.3 & 56.5 & 14.8 & 77.5 & 16.1 & 62.5 \\
\hline Truck Sh1pment & 15.6 & 10.5 & 24.3 & 5.6 & 12.4 & - & 15.2 \\
\hline Barge Shipment & 16.5 & 4.2 & 19.2 & - & - & - & 11.4 \\
\hline Total & 100.0 & 200.0 & 100.0 & 100.0 & 100.0 & 100.0 & 100.0 \\
\hline $\begin{array}{l}\text { Per cent each } \\
\text { grain was of } \\
\text { Total Volume }\end{array}$ & 31.2 & 38.3 & 24.1 & 3.4 & $2 \bullet 4$ & .6 & 100.0 \\
\hline
\end{tabular}


handled, corn represented 31.2 per cent, and soybeans made up 24.1 per cent. Therefore, these three grains accounted for 93.6 per cent of these elevators' entire volume, which left only 6.4 per cent to be made up by oats, sorghum grains, and barley.

Financing trucked grain shipments. The elevator operators who reportod selling grain which was shipped by truck were asked to Indicate the method of sale and the method of financing these shipments. The methods of financIng were listed as cesh or check, elevator financed, and advances from, or drafts on buyers or dealers pending settlement. The information which was obtalned is presented In Table XIX.

The most important method of sale category was reported to be direct sales based on country elevator weights and grades, and the most common method of financing was by cash or check. This type of transaction accounted for 37.6 per cent of the trucked grain shipments.

The next most important method of financing trucked grain shipments was advances from or drafts on buyers or dealers pending settlement. Th1s method of financing was reported to have been used for 33.7 per cent of the grain shipped by truck.

Approximately 28.7 per cent of the trucked grain shipments were elevator financed. This method of financing 
TABIE XIX

METHODS OF FINANCING TRUCKED GRAIN SHIPMENTS, EXPRESSED AS A PER CENT OF TOTAL VOLUNE OF GRAIN SHIPPED BY TRUCK, FIFTY-NINE COUNTRY ELEVATORS, MISSOURI, 1956

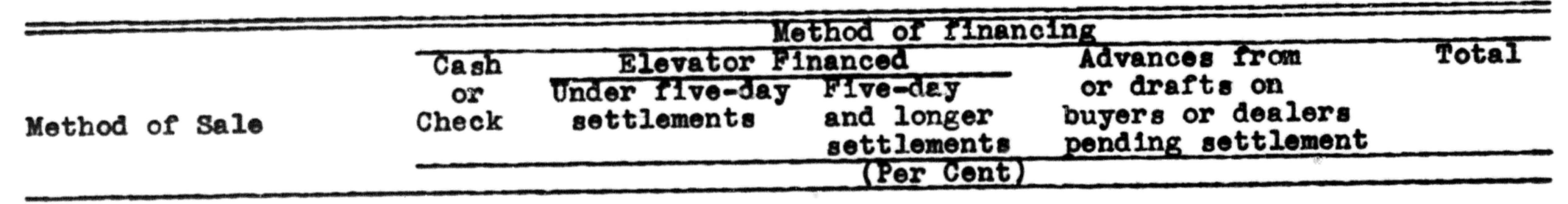

Direct sales based on country elevator. weights and grades 37.6

Direct (or spot) 88.10 to elevators or processors on destination weights and grade

$$
4.9
$$

$14 \cdot 6$

28.2

$47 \cdot 7$

Contract sales through

dealers, brokers, or commision firms on destination weights and gxado:

2.8

6.4

5.5

$14 \cdot 7$

Total

37.6

7.7

210

33.7

100.0 
was further broken down into under five-day settlements, and five-day and longer settlements. It was estimated that about 7.7 per cent were under five-day settlements, and that approximately 21.0 per cent of the trucked grain shipments were five-day and longer settlements. 


\section{CHAPTER V}

\section{QUALITY DETERMINATION OF GRAIN}

The determination of the quality of a commodity is very desirable when the commodity is to enter commercial market1ng channels. The quality determination processes are commonly referred to as grading. Without some standardlzed procedures for measuring quality and differentiating grades the marketing and pricing mechanism would be seriously impared, The buyer would have no ldea of the quality of his purchases unless he, or his representative, personally examined the commodity. However, much work remains to be done in the field of refining commodity grades.

Quality determination and standardization of grades inspire confidence and facilitate the exchange function at all levels in the marketing channel. Without grades and the use of somewhat uniform terminology, market reporting and price quotations would be made meaningless or impossible. Not only is the grading or quality determination of a commodity important, but also a standardized system of weights and measures is essential to orderly marketing. Without these, confusion and misunderstanding would exist throughout the marketing channel. The diverse units which are used in the United States today were inherited from the colonial days when the English settlers brought with them the weights and measures of the mother country. The history 
of some of the various units in England can be traced back to medieval times, but the actual origin of some of the units is doubtful.

The need for uniform weights and measures was recognized when the American Colonies united, and the power to establish them was given to the Federal Government. ${ }^{1}$ Although the Constitution gives the Federal Government power to regulate trade between states and with forelgn countries, there might be argument as to whether 1ts power to $11 x$ the standard of weights and measures covers regulation of market practices within a state. At any rate, the control of local use of we1ghts and measures has been largely left to state and local authorities. Th1s condition might be expected to lead to local or regional practices, but various influences have worked toward national uniformity. One is the rapid growth of interstate trade.2

The benefits of standardization and quality determination to the grain industry have been particularly important. For example, grain grading permits the economy of bulk storage and transportation of grain of similar grades. It facilitates financing and trading on the basis of warehouse certificates representing grain of known quality

\footnotetext{
1 The Yearbook of Agriculture: 1954. Marketing, op. c1t., p. $147-148$.

2 Ib1a.
} 
and value, and establishes loan values for grain in farm storage.

Grain grading, and market quotations based on grade, assist producers and handlers of grain to market their grain advantageously. The application of the grain standards shows the causes for market discounts, and indicates ways and means for crop-improvement and grain-handing practices that $w 11$ bring about a reduction of certain "off" grades of preventably low quality. Grain standards function as commercial measures of quality and condition. They assist in the economical marketing of grain because their use reduces risks and promotes definite agreements between contracting parties.3

\section{DEVELOPMENT OF GRAIN GRADING}

As the mid-west prairies and the Mississippl Valley were gradually brought under cultivation, an increasing quantity of surplus grain moved eastward to consuming centers and to the eastern seaboard by rail, river, canal, and lake. Thare was a need for a readily understandable commerc1al language to express the qual1ty, class, and condition of individual lots of grain so that buyers and sellers at separate points could trade without a personal inspection

${ }^{3}$ United States Department of Agriculture, Agriculture Handbook Number 59, Grain Grading Primer (Washington: Government Printing Office, 1953), p. 4. 
of the grain itself. Therefore, grain trade organization Instituted a system of grain grading whereby grain could be bought and sold by grade without having the grain or samples of 1t before the interested parties.

Each trade organization adopted 1ts own set of standards method of application. The grades themselves were set forth in rather ambiguous terms such as "dry," "damp," "plump," "well-cleaned," "unsound," and "urmerchantable".4 In some markets different interests favored different kinds of grain standards. Millers generally preferred high standards, whereas some others frequently favored more liberal standards, leniently applied. Persons buying grain under a certain designation in one market could not be sure that the grain would receive the same grade designation in some other market. Exporters who bought grain at interior markets for delivery abroad had no assurance that the grain bought by grade at interior points would be assigned the same grade when loaded aboard ship for export. Indefinite grading and the lack of confidence in grain grading had a tendency to depress prices of grain sold by grade, especially if delivery was to be made at some distant future date. For many years grain organizations tried to bring about a more consistent applicstion of uniform standards.

$$
{ }^{4} \text { Ib1d., pp. 2-3. }
$$


The demand for uniform grades and inspection resulted in many bills being introduced in the United States Congress during the years 1903 to 1916 providing for Federal supervision of grain grading or for outright Federal grain inspection. Finally, the United States Grain Standards Act was passed August 11, 1916. It provides in part for the establishment of official grain standards, Federal 11censIng and supervision of the work of grain inspectors, and the entertaining of appeals from the grades assigned by the licensed inspectors. 5

\section{GRAIN GRADING FACTORS}

Some of the tests of grain quality that are considered to be important are tests for cleanliness, soundness, dryness, purity of type, plumpness, and the general condition of the grain.

Various tests have been devised for determining these quality factors for grain. Some of the factors can be measured with mechanical devices, whereas others, such as odor and class, for example, must be determined by the grain grader mainly without the aid of mechanical means.

Cleanliness is measured by determining the foreign material content. This is known as dockage testing, and it is performed by the use of appropriate sieves and cleaning

\section{${ }^{5}$ Ib1d.}


devices. Plumpness is measured by the weight-per-bushel test, supplemented by sizing tests for some grains. Soundness is indicated by the absence of musty, sour, or commerclaily objectionate forelgn odors, and by the quantity of damaged kernels that are present in the grain. Dryness is determined by making a molsture test. An electric molsture meter is widely used for making this test. 6 Purity of type 1s provided for by classes for the various grain and by limitations for admixtures of other grains or of other classes of the same grain. The general term "condition" refers to whether the grain 18 in sound condition or is out of condition because it is musty, sour, or heating. The condition of grain is also indicated by such designations as "garlicky," "smutty," "weevily," and "bright."

Grain classes and sub-classes are also factors which are considered in grading grain. Some kinds of grain have several classes and sub-classes. Wheat, for example, is divided into seven classes, some of which have as many as three sub-classes.7

The protein content of wheat has begun to receive attention from consumers and the grain trade. Although it

\section{${ }^{6}$ Ib1d., pp. 5-27.}

7United States Department of Agriculture, Agricultural Marketing Service, Grain Division, Official Grain Standards of the United States (Washington: Government Printing office, I957), p. I. 
is not a grade factor for wheat, it is quoted and priced separately. The premium pald for high-protein wheat 1s based on the percentage of protein contained in the wheat, not for protein by weight. ${ }^{8}$

At the country grain elevator level in the grain marketing channel, the testing for grade factors is usually performed by the elevator operator or h1s employee. Object1ve type tests for molsture and test-we1ght are usually made, but subject1ve tests are commonly used for the other grade factors. From a study made in 1955, Temple reported that 94 per cent of the country elevator operators indicated that they used objective methods for determining molsture content and test we1ght. A smaller percentage of the operators reported using objective tests for other graln grading factors such as damaged kernels, and forelgn material. ${ }^{9}$ When the grain reaches terminal markets officlal grades are determined by 11 censed grain inspectors.

Practices in grain sampling. The first essential step in grading grain is to obtain a correct and representat1ve sample of the lot of grain to be graded. At the

${ }^{8}$ Ci1ve B. Harston, Market1ng H1gh-Protein Wheat in the Northern Great Pla1ns," Agr1cultural Econom1cs Research, Apr11, 1957, Agricultural Re search Serv1ce, Un1ted Strites Departmont of Agriculture (Washington: Government Printing Off 1ce, 1957), pp. 54-62.

$$
\text { 9 Temple, ov. c1t., p. } 72 \text {. }
$$


country grain elevator level it is at the discretion of the elevetor operator whether or not to sample the loads of grain which he buys, and which sampling techniques be will use. Although he cannot assign an offelal grade to the grain that he buys, it is to his own advantage and in fairness to the producer of promium quality to sample and test 1t. Otherwise, should he buy grain with a high molsture content, he has the risk of loss due to spollage. He will stand a loss from dockage when the grain is graded at the terminal market if it contains a large amount of foreign material. Thus, 1t is necessary for the elevator operator to sample and test grain in order to protect himself from finencial loss and to encourage producers to improve the quality of their grain.

Regulations and instructions for grain sampling which are to be followed for determining the official grades are published by the Department of Agriculture, in its administration of the Grain Standards Act. The licensed grain inspector's sampling techniques must conform to these standards. 10

Information which was obtained from this study of fifty-nine Missouri country grain elevators indicated that most of the loads of grain brought in by farmers were sampled. During harvest time it was reported that an average

10 official Grain Standards, op. c1t., p. 84. 
of about 80.7 per cent of the loads of corn arriving at these country elevators were sampled. The average percentage of the loads of wheat, soybeans, and oats that were sampled during harvest time were $96.0,97.4$, and 85.1 per cent, respectively. A slightly higher percentage of the loads of all these grains were reported to have been sampled when they were sold to the elevator after the harvest season was over.

Changes in grain grading practices since 1946. The fifty-nine Missourl country grain elevator operators who were interviewed for this study were asked to indicate whether grain grading practices in their locality had tightened, not changed, or had loosened over the past ten year period. This information is presented in Table XX. A majority of the elevator operators reported a tightening of grading practices for each of the major grains. However, it appeared that wheat and soybeans were particularly affected. No elevator operator reported a loosening of grading practices for any of the grains. Some of the elevator operators mentioned that the Pure Food and Drug Laws had tightened in respect to tolerance of rodent damage to grain which was to be used for human consumption. This would cause the elevator operator to tighten his grailing practices concerning tine Poreign material content, particularly. 
TABIE XX

CHANGES IN GRADING PRACTICES SINCE 1946 OF

FIFTY-NINE COUNTRY ELEVATORS

MISSOURI, 1966

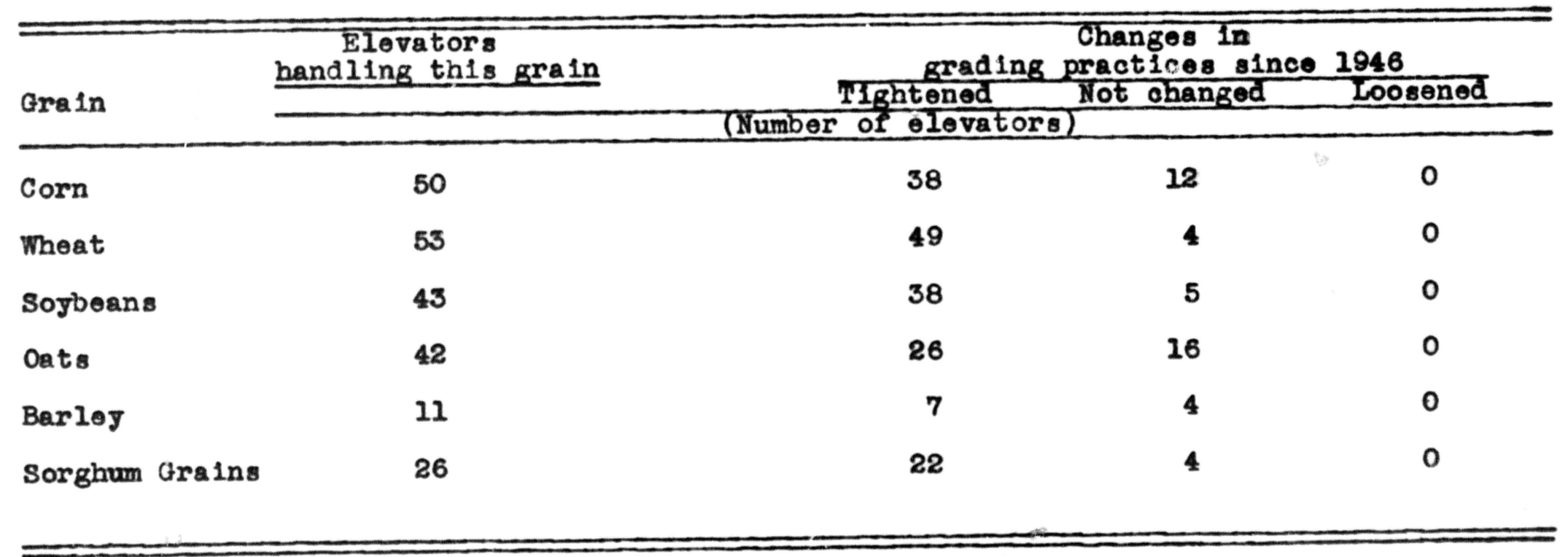


Grain merchandising practices. Blending, cleaning, scalping, and artificial arying are practices which are commonly performed in connection with grain merchandising. These conditioning processes are used in order to increase the value of the grain; or prevent deterioration in 1ts qual1ty.

In this study of fifty-nine Missouri country grain elevators, twenty-four were reported to be equipped to blend different qualities of grain. It was reported that approximately 12 per cent of the grain shipped by these country elevator operators was conditioned in some manner for shipment. About 88 per cent of the grain was reported to have been shipped as purchesed. 


\section{CHAPTER VI}

\section{SUMMARY AND CONCLUSIONS}

The production and marketing of grain is one of the most important businesses in M1ssour1. In 1956 M1ssour 1 farmers recelved an income from the sale of grain of approximately $\$ 252,713,000$. This amount does not include the value of the grain marketed through livestock and 11vestock products.

Country grain elevators provide the sales outlet for about 80 to 90 per cent of the grain which farmers sell. Their pricing and trading practices are of much importance to the grain producer.

Missours is an important producer of all of the major grains grown in the United States. In 1956 it ranked between fifth and ninth place among all states in the production of the seven major grain crops.

The state of Missour1 is divided into nine Crop Reporting Districts. District I (Northwest) accounted for an average of about 20.6 per cent of the total grain produced in Missouri during the ten year period 1946 to 1955. This made it the leading grain producing District in Missour1. It was an especially important producer of corn. During this same ten year period, District VIII (South Central) accounted for the smallest average percentage of 
the state's grain production, with approximately 2.9 per cent of the state's totel.

The fifty-nine Missourl country grain elevators that were included in this study had an average storage capacity of 49,000 bushels. Their average volume of grain handied In 1956 was 243,000 bushels, thus the ratio of volume handled to storage capacity was approximately 4.9:1. Information which was obtained for this study indicated that terminal quotations, and carlot dealers or brokers are the principal sources of pricing information for Missouri country grain elevator operators. The elevator operators who were interviewed reported that an average of approximately 86.9 per cent of the total bushels of Erain which they bought was based on pricing information that was obtained from these agencies. They indicated that home offices were the source of about 5.3 per cent of their pricing information, with processors, truckers, and local feeders accounting for the remeinder. There seemed to have been no significant changes in the sources of pricing information during the past ten years.

The fifty-nine Missouri country grain elevator operators who were interviewed for this study reported an average gross margin on rall shipments of corn, wheat, soybeans, and oats of 7.2 cents, 7.6 cents, 8.2 cents, and 6.7 cents per bushel, respectively. For truck shipments, the average gross margins were 7.7 cents, 7.4 cents, 7.5 cents, 
and 7.5 cents per bushel for corn, wheat, soybeans, and oats, respectively. For local sales, an average gross margin of 8.8 cents per bushel was reported for corn, and 8.7 cents per bushel for oats. A majority of the elevator operators reported that there had been no change in their gross margins during the past ten years. Those who reported a change in their gross margins, almost without exception, Indicated that they were now lower. Increased competition was usually reported as being responsible for this.

Terminal markets are the most important sales outlet for the grain sold by country grain elevator operators in Missouri. The elevator operators who were interviewed for this study reported an average of about 72.4 per cent of the total volume of all grain which they handled was sold to terminal or sub-terminal agencies. This percentage was higher for certain kinds of grain such as wheat, for example. Local sales to l1vestock feeders was an important sales outlet for oats. Other sales outlets reported by these elevetor operstors were processors, truckers, and exporters.

The elevator operators who were interviewed for this study reported rail shipment to be the most important method of transportation used for the grain which they sold. They indicated that an average of about 62.5 per cent of their total volume of grain was shipped by rail, 15.2 per cent by truck, and 11.4 per cent by barge. Approximately 10.9 per 
cent of their grain was sold locally, in which case the livestock feeder would usually haul the grain to the farm himself.

Quality determination, or grading, is essential to the orderly marketing of grain. One important benefit of the standardization of grain grades is that it provides for the great economies of bulk storage. Officlal grades are assigned to grains by licensed inspectors, usually at major points of concentration, such as the terminal markets. At the country grein elevator level, test for moisture and weight per bushel are the most common objective type tests that ere made. However, information which was obtained from this study indicated that country grain elevator operators had tightened their grading practices, especially concerning foreign material, during the past ten years. Much work remains to be done in the field of refining commodity grades.

This study has been an attempt to make some contribution to the fleld of knowledge concerning the marketing of grain. It is realized by the writer that continuing effort must be exerted in this field in order that current information may be avallable relating to the dynamic situation that exists today in grain marketing. 
BIBLIOGRAPHY 
Grain Market1ng Effic1ency, The Story of the Kansas C1ty Board of Trade. EducationaI Committeo, Kansas City Board of Trade, Kansas C1ty, M1ssour1, 1954.

Harston, Cl1ve R., "Marketing High-Protein Wheat in the Northern Great Plains," Agricultural Economics Research, Apr11, 1957 .

Kohls, R1chard I. Harket1ng of Agricultural Products. New York: The Macmilian Company, 1955.

M1ssour1 Farm Census by Count1es, 1946 to 1955, M18sour1 State Department of AgricuIture, Jefferson C1ty, M18 sour1.

N1nety-E1ghth Annual Report, Board of Trade of the C1ty of Chicago. Chicago: Lincoln Printing Company, 1956.

Ninety-Ninth Annual Report, Board of Trade of the City of ChIcago. Chicago: Lincoln Printing Company, 1957.

Temple, Norman F. "Characteristics of Country Elevators in Missour1 as They Relate to Grain Marketing." Unpublished Master's thesis, University of M1ssour1, Columb1a, 1955.

Thomsen, Frederick L., and Foote, Richard J. Agricultural Prices. New York: McGraw-H1ll Book Company, Inc., 1952.

Un1ted States Department of Agriculture, Agricultural Handbook Number 59, Grain Grading Primer. Washington: Government PrInt Ing Oef1ce, 1955.

United States Department of Agriculture, Agricultural Stat1st1c8 1953, and 1956. Washington: Government Printing of Pice.

United States Department of Agriculture, Agricultural Marketing Service, Washington, D. C. Crop Production, July, 1957, and October 1957. 
Un Pred States Department of Agriculture, Agricultural Marketing Service, Grain Division, Washington, D. C. Grain Market News, Fobruary 3, April 6, June i, August 3, and October 5, 1856; January 4, Apr11 5, July 5, and July 12, 1957.

United States Department of Agriculture, Agricultural Marketing Service, Grain Division. Official Grain Standards of the United States. Washington: Governinent Srinting Office, 1957.

United States Department of Agriculture, Agricultural Marketing Service, Agricultural Economics Division. Statist1cal Bullet in Number 159, Grain and Foed Statistic8. Washington: Government Printing Office, 1957.

United States Department of Agriculture. The Yearbook of Agriculture: 1954. Market1ng. Washington: Government Printing OPfIce, 1954 . 
A P PENDIX 
AVERAGE PRICE PER BUSHEL RECEIVED BY FARMERS, AND AVERAGE PRICE PER BUSHEL PAID AT A TERMINAL MARKET FOR CORN, 1946 - 1956 (Dollars per bushel)

\begin{tabular}{|c|c|c|c|c|c|c|c|c|c|c|c|c|}
\hline \multirow[b]{2}{*}{ Year } & \multicolumn{9}{|c|}{ M18sour1 Crop Reporting D1stricts* } & \multirow{2}{*}{$\begin{array}{l}\text { Mo.* } \\
\text { state } \\
\text { Av. }\end{array}$} & \multirow{2}{*}{$\begin{array}{c}\text { U.S.H* } \\
\text { Av. }\end{array}$} & \multirow{2}{*}{$\begin{array}{l}\text { Kans. C. } \\
\text { Term。t } \\
\text { Av. }\end{array}$} \\
\hline & I & II & III & IV & V & VI & VII & VIII & IX & & & \\
\hline $\begin{array}{l}1946 \\
1947 \\
1948 \\
1949 \\
1950 \\
1951 \\
1952 \\
1953 \\
1954 \\
1955 \\
1956\end{array}$ & $\begin{array}{r}\$ 1.38 \\
1.93 \\
1.93 \\
1.17 \\
1.32 \\
1.66 \\
1.73 \\
1.44 \\
1.50 \\
1.38 \\
1.35\end{array}$ & $\begin{array}{r}\$ 1.35 \\
1.89 \\
1.96 \\
1.13 \\
1.29 \\
1.63 \\
1.71 \\
1.41 \\
1.52 \\
1.33 \\
1.28\end{array}$ & $\begin{array}{r}\$ 1.39 \\
1.91 \\
1.99 \\
1.13 \\
1.30 \\
1.62 \\
1.65 \\
1.43 \\
1.49 \\
1.31 \\
1.26\end{array}$ & $\begin{array}{r}\$ 1.38 \\
1.90 \\
1.90 \\
1.17 \\
1.35 \\
1.68 \\
1.78 \\
1.45 \\
1.54 \\
1.39 \\
1.32\end{array}$ & $\begin{array}{r}\$ 1.49 \\
1.94 \\
2.01 \\
1.23 \\
1.36 \\
1.70 \\
1.77 \\
1.47 \\
1.54 \\
1.40 \\
1.31\end{array}$ & $\begin{array}{r}\$ 1.41 \\
1.91 \\
1.99 \\
1.18 \\
1.35 \\
1.68 \\
1.71 \\
1.44 \\
1.53 \\
1.36 \\
1.26\end{array}$ & $\begin{array}{r}1.47 \\
1.91 \\
1.93 \\
1.23 \\
1.36 \\
1.69 \\
1.76 \\
1.53 \\
1.56 \\
1.44 \\
1.39\end{array}$ & $\begin{array}{r}\$ 1.54 \\
1.90 \\
1.99 \\
1.23 \\
1.38 \\
1.65 \\
1.73 \\
1.52 \\
1.54 \\
1.42 \\
1.32\end{array}$ & $\begin{array}{r}\$ 1.40 \\
1.78 \\
1.92 \\
1.19 \\
1.37 \\
1.66 \\
1.74 \\
1.52 \\
1.48 \\
1.34 \\
1.26\end{array}$ & $\begin{array}{r}\$ 1.41 \\
1.91 \\
1.96 \\
1.17 \\
1.33 \\
1.66 \\
1.73 \\
1.45 \\
1.52 \\
1.37 \\
1.30\end{array}$ & $\begin{array}{r}1.41 \\
1.87 \\
1.88 \\
1.17 \\
1.33 \\
1.62 \\
1.64 \\
1.44 \\
1.46 \\
1.30 \\
1.30\end{array}$ & $\begin{array}{r}\$ 1.49 \\
2.03 \\
2.01 \\
1.31 \\
1.43 \\
1.76 \\
1.81 \\
1.58 \\
1.59 \\
1.48 \\
1.50\end{array}$ \\
\hline
\end{tabular}

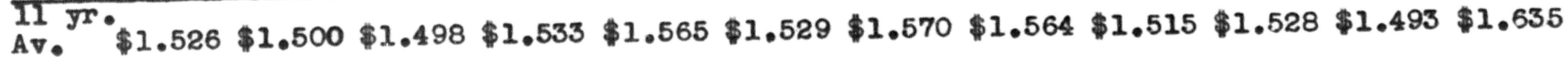

* State Agricultural statistician. Simple average of monthly prices. HSDA AMS. Grain and Foed Stat1st1cs Through 1956, Statist1cal Bulletin No. 159 (Wa shington: Government Printing of $110 \theta, 1957$ ), p. 37. Crop year average by States, weighted by 88108 to obtain weighted average for the $\mathrm{S}$.

* *USDA, AMS, Grain Market News, October 5, 1956 and Apr17 5, 1957. S1mple average of daily closing cash prices Kansas City for No. 2 Yellow Corn. 
TABLE II

AVERAGE PRICE PER BUSHEL RECEIVED BY FARMERS, AND AVERAGE PRICE

PER BUSHEI PAID AT A TERMINAL MARKET FOR WHEAT, 1946 - 1956 (Dollars per bushel)

\begin{tabular}{|c|c|c|c|c|c|c|c|c|c|c|c|c|}
\hline \multirow[b]{2}{*}{ Year } & \multicolumn{9}{|c|}{ M1ssour1 Crop Reporting Districtst } & \multirow{2}{*}{$\begin{array}{c}\text { Mo } \\
\text { state } \\
\text { Av. }\end{array}$} & \multirow{2}{*}{$\begin{array}{l}\text { U.S.t.\% } \\
A \nabla \bullet\end{array}$} & \multirow{2}{*}{$\begin{array}{c}\text { Kans. C. } \\
\text { Term.* } \\
\text { Av. } \\
\end{array}$} \\
\hline & I & II & III & IV & $\mathrm{v}$ & VI & VII & VIII & IX & & & \\
\hline $\begin{array}{l}1946 \\
1947 \\
1948 \\
1949 \\
1950 \\
1951 \\
1952 \\
1953 \\
1954 \\
1955 \\
1956\end{array}$ & $\begin{array}{r}\$ 1.77 \\
2.38 \\
2.24 \\
1.93 \\
2.02 \\
2.19 \\
2.18 \\
2.01 \\
2.06 \\
2.03 \\
2.01\end{array}$ & $\begin{array}{r}1.78 \\
2.41 \\
2.19 \\
1.87 \\
1.94 \\
2.13 \\
2.12 \\
1.93 \\
1.95 \\
1.96 \\
1.95\end{array}$ & $\begin{array}{r}\$ 1.79 \\
2.42 \\
2.24 \\
1.90 \\
1.97 \\
2.15 \\
2.13 \\
1.88 \\
1.94 \\
1.89 \\
1.93\end{array}$ & $\begin{array}{r}\$ 1.77 \\
2.38 \\
2.17 \\
1.92 \\
1.99 \\
2.14 \\
2.16 \\
2.00 \\
2.04 \\
2.01 \\
1.99\end{array}$ & $\begin{array}{r}\$ 1.81 \\
2.40 \\
2.18 \\
1.87 \\
1.93 \\
2.10 \\
2.07 \\
1.87 \\
1.90 \\
1.91 \\
1.88\end{array}$ & $\begin{array}{r}\$ 1.84 \\
2.47 \\
2.23 \\
1.90 \\
1.98 \\
2.16 \\
2.11 \\
1.87 \\
1.94 \\
1.88 \\
1.95\end{array}$ & $\begin{array}{r}\$ 1.78 \\
2.34 \\
2.14 \\
1.87 \\
1.97 \\
2.17 \\
2.17 \\
1.98 \\
2.03 \\
1.98 \\
1.95\end{array}$ & $\begin{array}{r}\$ 1.85 \\
2.41 \\
2.27 \\
1.88 \\
1.96 \\
2.10 \\
2.08 \\
1.89 \\
1.88 \\
1.87 \\
1.85\end{array}$ & $\begin{array}{r}\$ 1.86 \\
2.44 \\
2.25 \\
1.95 \\
2.01 \\
2.17 \\
2.15 \\
1.88 \\
1.91 \\
1.91 \\
1.95\end{array}$ & $\begin{array}{r}\$ 1.81 \\
2.41 \\
2.21 \\
1.90 \\
1.98 \\
2.15 \\
2.14 \\
1.94 \\
1.98 \\
1.96 \\
1.95\end{array}$ & $\begin{array}{r}\$ 1.74 \\
2.35 \\
2.15 \\
1.92 \\
1.96 \\
2.12 \\
2.12 \\
1.99 \\
2.05 \\
2.02 \\
1.98\end{array}$ & $\begin{array}{r}\$ 1.89 \\
2.56 \\
2.34 \\
2.16 \\
2.23 \\
2.40 \\
2.40 \\
2.26 \\
2.32 \\
2.25 \\
2.22\end{array}$ \\
\hline
\end{tabular}

* State Agricultural statistician. Simple average of monthly prices. \#\#CSDA, AMS, Grain Market News, July 12, 1957.

* USDÁ, AMS, Grain Market Nows, July 5, 1957. simple average of daily closing cash prices at Kansas C1ty For No. 2 Hard Red Winter, Ordinary Protein Wheat. 
TABLE III

AVERAGE PRICE PER BUSHEL RECEIVED BY FARMERS, AND AVERAGE PRICE

PER BUSHEL PAID AT A TERMINAL MARKET FOR SOYBEANS, 1946 - 1956 (Dollars per bushel)

\begin{tabular}{|c|c|c|c|c|c|c|c|c|c|c|c|c|}
\hline \multirow[b]{2}{*}{ Year } & \multicolumn{9}{|c|}{ M18sour1 Crop Reporting D1stricts } & \multirow{2}{*}{$\begin{array}{l}\text { Mo॰* } \\
\text { State } \\
\text { Ave. }\end{array}$} & \multirow{2}{*}{$\begin{array}{l}\text { U.S. } \\
\text { Av. }\end{array}$} & \multirow{2}{*}{$\begin{array}{l}\text { Chicago } \\
\text { Term } \\
\text { Av. }\end{array}$} \\
\hline & I & II & III & IV & v & VI & VII & VIII & IX & & & \\
\hline $\begin{array}{l}1946 \\
1947 \\
1948 \\
1949 \\
1950 \\
1951 \\
1952 \\
1953 \\
1954 \\
1955\end{array}$ & $\begin{array}{r}\$ 2.31 \\
3.34 \\
2.97 \\
2.16 \\
2.39 \\
2.82 \\
2.78 \\
2.56 \\
2.94 \\
2.50 \\
2.36\end{array}$ & $\begin{array}{r}\$ 2.33 \\
3.24 \\
3.10 \\
2.10 \\
2.38 \\
2.84 \\
2.81 \\
2.57 \\
2.99 \\
2.26 \\
2.36\end{array}$ & $\begin{array}{r}\$ 2.36 \\
3.30 \\
3.19 \\
2.15 \\
2.44 \\
2.89 \\
2.87 \\
2.65 \\
3.07 \\
2.34 \\
2.44\end{array}$ & $\begin{array}{r}\$ 2.36 \\
3.24 \\
2.92 \\
2.15 \\
2.43 \\
2.81 \\
2.78 \\
2.53 \\
2.97 \\
2.24 \\
2.31\end{array}$ & $\begin{array}{r}\$ 2.51 \\
3.24 \\
3.19 \\
2.17 \\
2.41 \\
2.85 \\
2.81 \\
2.55 \\
2.97 \\
2.23\end{array}$ & $\begin{array}{r}\$ 2.21 \\
3.10 \\
3.10 \\
2.12 \\
2.41 \\
2.87 \\
2.83 \\
2.56 \\
3.00 \\
2.25\end{array}$ & $\begin{array}{r}\$ 2.43 \\
3.22 \\
3.05 \\
2.11 \\
2.46 \\
2.83 \\
2.76 \\
2.50 \\
2.78\end{array}$ & $\begin{array}{r}\$ 2.67 \\
2.94 \\
3.33 \\
2.16 \\
2.48 \\
2.89 \\
2.90 \\
2.69 \\
2.83 \\
2.34 \\
2.41\end{array}$ & $\begin{array}{c}\$ 2.4 \\
3.0 \\
3.0 \\
2.0\end{array}$ & $\begin{array}{r}\$ 2.39 \\
3.18 \\
3.02 \\
2.12 \\
2.40 \\
2.86 \\
2.81 \\
2.59 \\
2.97 \\
2.28\end{array}$ & $\begin{array}{l}2.89 \\
2.82 \\
2.61 \\
3.04 \\
2.28 \\
2.40\end{array}$ & $\begin{array}{l}19 \\
16 \\
13 \\
16 \\
74 \\
12 \\
77 \\
36 \\
32 \\
50 \\
53\end{array}$ \\
\hline
\end{tabular}

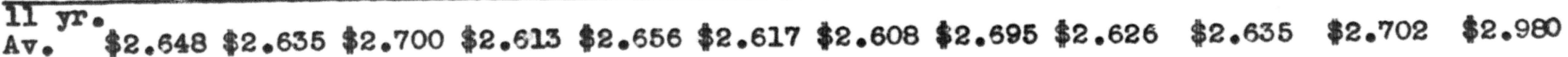

* State Agricultural statistician. Simple average of monthly prices.

- State Agricultural AMS, Grain Market New8, February 5, Apr11 6, June 1, August 3, October 5, 1956, and January 4, 195/ for the year 1956.

HHWSDA, AMS, Grain Market News, October 5, 1956 and April 5, 1957, p. 9. S1mple average of daliy closing cash prices for No. I Yeilow Soybeans (prior to October 1953, quotet1ons were based on No. 2 Yellow Soybeans). 


\section{TABLE IV}

AVERAGE PRICE PER BUSHEL RECEIVED BY FARMERS, AND AVERAGE PRICE

PER BUSHEL PAID AT A TERMINAL MARKET FOR OATS, 1946 - 1956 (Dollars per bushel)

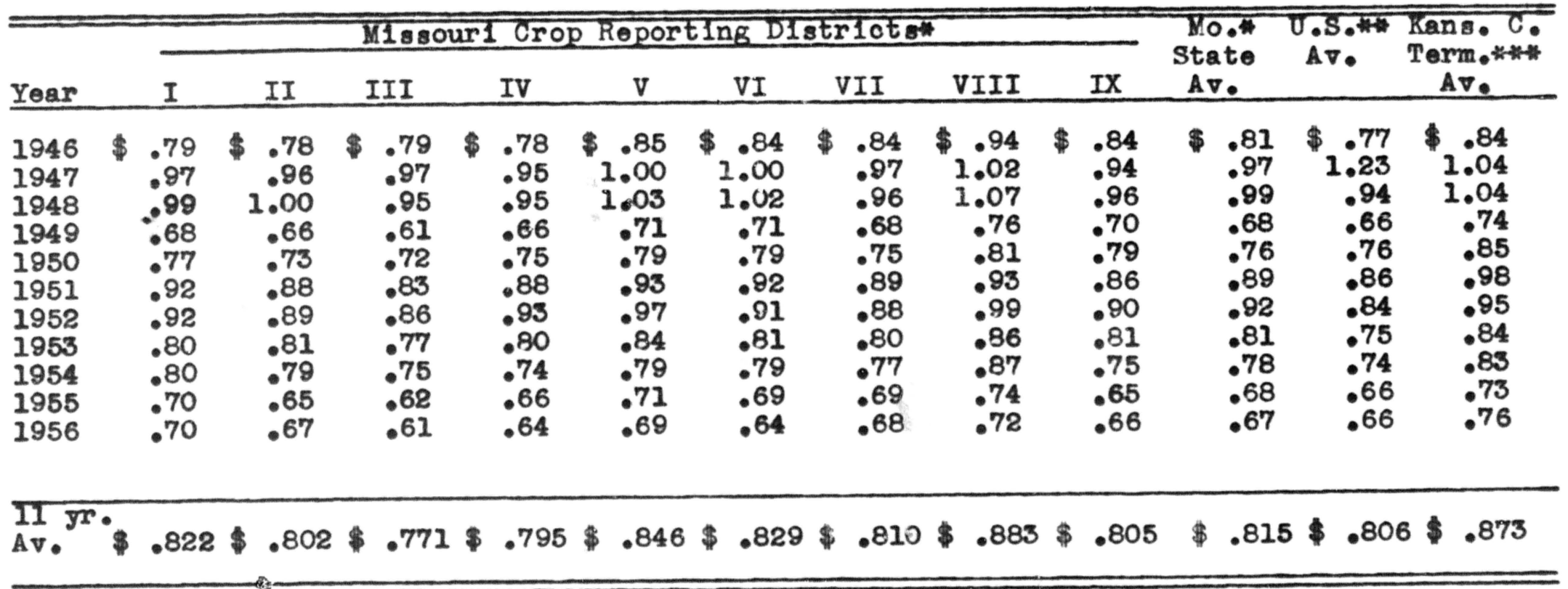

* State Agricultural statist1clan. Simple average of monthly prices.

*USDA, AMS, Grain and Foed Statist1cs Through 1956, Statistical Builetin Number 159, (Washingt on: Government Printing orfice, 1957), p. 39 . *H USDA, AMS, Grain Market News, July 5, 1957. Simple average of daily closing cash prices at Kansas C1ty for No. 2 White Oato 


\section{TABLE V}

PER CENT OF GRAIN SOLU FROM THE FARM, 1955*

\begin{tabular}{lcc}
\hline Grain & $\frac{\text { Missour1 }}{\text { (Percent) }}$ & $\frac{\text { United States }}{(\text { Per cent) }}$ \\
\hline Corn & 26.0 & 31.1 \\
Wheat & 89.6 & 89.7 \\
Oats & 19.0 & 25.2 \\
Sojbeans & 96.1 & 95.2 \\
Barley & 17.0 & 63.6 \\
Sorghum Grains & 44.0 & 74.8 \\
Rye & 62.2 & 73.9 \\
\hline Weighted Average, all graing & 41.9 & 45.0 \\
\hline \hline
\end{tabular}

*Agricultural Stat1st1c8 1956, Un1ted States Department of Agriculturo, Wasington, D. C. 
TABIE VI

PER CENT OF THE STATE'S TOTAL NUMBER OF EACH CLASS OF LIVESTOCK IN EACH DISTRICT, MISSOURI, JANUARY 1, 1956*

\begin{tabular}{lrrrr}
\hline \hline D1str1ct & $\begin{array}{c}\text { AII } \\
\text { Cattle } \\
\text { (per cent) }\end{array}$ & $\begin{array}{c}\text { Hogs } \\
\text { (per cent) }\end{array}$ & $\begin{array}{c}\text { Stock } \\
\text { Sheep } \\
\text { (per cent) }\end{array}$ & $\begin{array}{c}\text { Ch1ckens } \\
\text { (per cent) }\end{array}$ \\
\hline I (Northwest) & 16.4 & 26.6 & 21.1 & 13.8 \\
II (North Central) & 11.7 & 12.2 & 27.3 & 11.9 \\
III (Northeast) & 8.8 & 13.0 & 17.0 & 9.6 \\
IV (West) & 11.6 & 9.6 & 8.8 & 12.8 \\
V (Central) & 18.7 & 14.8 & 12.6 & 16.8 \\
VI (East) & 8.1 & 10.0 & 3.3 & 12.4 \\
VII (Southwest) & 10.4 & 3.2 & 6.9 & 9.0 \\
VIII (South Central) & 10.3 & 5.3 & 2.5 & 7.9 \\
IX (Southeast) & 4.0 & 5.3 & .5 & 5.8 \\
\hline State Total (per cent) & 100.0 & 100.0 & 100.0 & 100.0 \\
State Total (head) & $4,027,000$ & $3,819,000$ & 749,000 & $14,555,000$ \\
\hline \hline
\end{tabular}


University Libraries

University of Missouri

Digitization Information for Theses and Dissertations project. Scanned from microfilm; no subsequent editing done.

Local identifier

Source information

Identifier

Format

Content type

Notes

Capture information

Date captured

Scanner manufacturer/model ScanPro 3000 /e-ImageData

Scanning software

Optical resolution

Compression

Color settings

File types

Notes

Derivatives - Access copy
Microfilm reel\# T1958-59-T1958-70

Microfilm

Text

2019

PowerScan $3000(\mathrm{TM})$ V5.341

$600 \mathrm{dpi}$

LZW

bitonal

tiff

Scanned from microfilm; no editing done.
Editing software

Resolution

Color

File types

Notes
Photoshop

600 dpi

grayscale

pdf

Converted from tiff to pdf using Adobe Acrobat Pro DC. 